\title{
Optimal Location of Energy Dissipation Outrigger in High-rise Building Considering Nonlinear Soil-structure Interaction Effects
}

\author{
Reihane Tavakoli ${ }^{1}$ Reza Kamgar², Reza Rahgozar ${ }^{1 *}$ \\ ${ }^{1}$ Department of Civil Engineering, Faculty of Engineering, Shahid Bahonar University of Kerman, Kerman, P.O. Box 7616913439, Iran \\ 2 Department of Civil Engineering, Faculty of Technology and Engineering, Shahrekord University, Shahrekord, P.0. Box 88186-34141, \\ Iran \\ *Corresponding author, e-mail: rahgozar@uk.ac.ir
}

Received: 12 July 2019, Accepted: 21 May 2020, Published online: 18 June 2020

\begin{abstract}
Buckling-restrained braces (BRBs) emerged to improve the seismic performance of high-rise structures as compared to the ordinary diagonal bracing. In this paper, the seismic performance of braced buildings with the BRB outrigger system is investigated to determine the optimal configuration of BRB outrigger, considering the nonlinear SSI effect. For this purpose, the nonlinear dynamic analysis is carried out on four braced buildings with a BRB outrigger system placed on three different soil types. The outrigger configuration changes from first to the top story to capture the seismic performance of different locations of BRB outrigger. It is observed that the outrigger location affects the seismic performance, which is measured in terms of inter-story drift ratio, story displacement, story shear, and energy dissipation capacity. The results are compared to the fixed base condition buildings, which proves considering SSI, shifts the optimal location to the upper story of the structure. Moreover, the effect of soil's stiffness on the seismic responses of structures and the optimal BRB outrigger location is investigated. Finally, the merits of BRB outrigger are shown by comparing its seismic performance that of the conventional outrigger, under frequent, basic, and rare earthquakes. The results show that the optimal locations of different 2-D buildings rested on the dense soil, medium soil, and soft clay are obtained at 0.6, 0.65 , and 0.7 of the building's height $(H)$, respectively. Also, the results show that the optimum location of the BRB outrigger system based on the energy dissipation criteria is $0.45 \mathrm{H}$ to $0.65 \mathrm{H}$.
\end{abstract}

Keywords

energy dissipation, soil-structure interaction, buckling-restrained brace, outrigger, earthquake

\section{Introduction}

The outrigger system that connects the central core of braced frames or shear walls to the outer frame is one of the effective structural systems to sustain lateral loading in tall buildings [1-8]. The seismic performance of this system is highly dependent on the outrigger location. Several studies have been carried out to evaluate the lateral response of the outrigger system and to find the optimal elevation of outrigger [9-19]. The presence of outrigger in an outrigger braced system reduces the inter-story drift by engaging the perimeter columns and increases the lateral stiffness; however, it causes a difference in lateral stiffness of strengthened story in comparison to the adjacent stories [20]. In traditional outrigger systems that are composed of ordinary braces, the members may buckle and show low ductile and unstable hysteresis behavior.
This is due to that the members undergo large lateral displacement subjected to strong seismic excitation [21].

A new generation of energy-dissipation or damped outriggers has been proposed to overcome the disadvantages and shortcomings of conventional outrigger systems. The damper devices are inserted to the outrigger truss ends and dissipate energy through relative vertical deformation between the outer column and outrider truss ends. This new system enhances damping instead of increasing lateral stiffness. The optimum location of the damped outrigger system has been evaluated to obtain a maximum damping ratio based on eigenvalue analysis [22, 23]. Other studies have been carried out to achieve seismic performance and optimal location of damped outrigger incorporating viscous dampers $[24,25]$. In recent researches, to further 
improve the seismic performance of the outrigger system in tall buildings, a new structural system with buckling restrained braces (BRBs) has been introduced, and the seismic performance of high-rise structures have been studied by several researchers [26-28]. BRBs are usually cheaper and more reliable than viscous dampers and are utilized to improve hysteresis behavior and enhance the ductility and drift capacity of the outrigger system [29,30]. In this study, $\mathrm{BRBs}$ are replaced with the ordinary diagonal braces in the outrigger system, and the seismic performance of this new system is compared to the traditional one.

The seismic performance of a structure [31-35] is affected by mutual interaction with its foundation and underlying soil media [36, 37]. Except for the case in which the structure is founded on a rigid rock base, assuming a structure with a fixed base and ignoring soil-structure interaction, particularly in seismic excitation, is not a logical assumption [38-41]. Pap and Kollár [42] studied the eigenmodes for the case in which the soft soil is bounded by rocks. They investigated the resonance effects on the response of the structure. Papadopoulos et al. used a finite element perfectly matched layers model to identify the importance of SSI on modal characteristics of a two-dimensional structure [43]. Lu et al. carried out a three-dimensional finite element analysis of a tall building incorporating SSI effects. They considered the effects of different criteria like soil property, the structure rigidity, and buried depth on seismic features of the structure [44]. Cruz and Miranda studied the SSI effect on the variation of the damping ratio of a structure under seismic excitation [45]. Raychowdhury [46] focused on the nonlinear SSI effect on seismic performance of steel moment-resisting frames measured in terms of ductility demand, base shear, base moment, and drift ratio. Finally, the results were compared with those obtained from fixed-base and elastic-base models. Torabi and Rayhani [47] studied the nonlinear soil-structure interaction response under earthquake loading. They modeled the structure as a linear elastic single degree of freedom model and used a nonlinear elastic-plastic behavior to represent soil behavior. Structure response was measured in terms of natural frequency, foundation motion, and base shear demand. The results showed all responses are influenced by SSI.

Normal outrigger systems (NOR) with conventional diagonal braces do not have a stable hysteresis behavior duo to the post-buckling behavior of outrigger. Indeed, in the NOR systems, the buckling happens first, and then compression yielding occurs, which results in large deformations and leads to large cyclic rotations at the end of the brace members (plastic hinges). A new generation of damped or energy dissipation outrigger systems was proposed to overcome the deficiency related to the NOR system. In this new system, the restrained buckling braces (BRBS) are replaced with the ordinary ones. BRBs increase compressive strength up to tensile yield strength. In fact, outrigger's buckling is delayed until yielding, which makes a stable hysteresis behavior for the system and increases ductility and the amount of dissipated energy significantly. The comparison of the hysteresis curve of normal and BRB braces is shown in Fig. 1.

In seismic excitation, the input earthquake motion is applied to the soil underlying the structure. The presence of soil alters the input motion and causes it to be different from free-field motion. Reciprocal effects that structure, foundation, and underlying geologic media have on each other, change vibrational properties of them that are known as SSI effects. These effects are categorized into two main mechanisms: kinematic and inertial interaction. Movement and rocking of the foundation under seismic motion alter the foundation input motion (kinematic interaction) and change the overall system behavior, including damping and

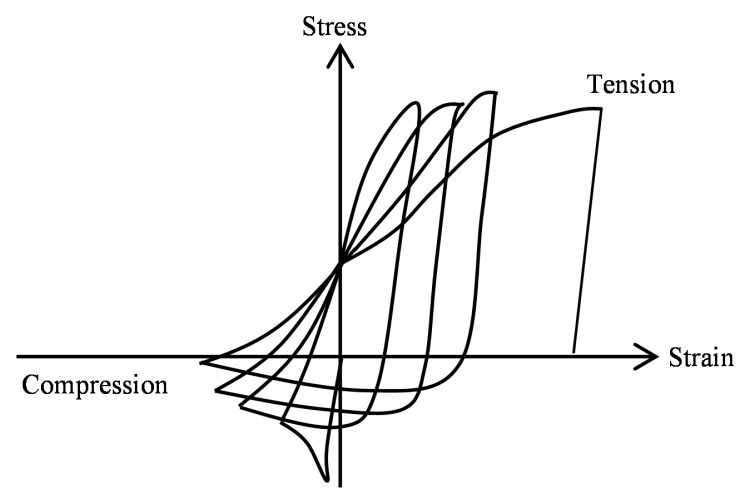

(a)

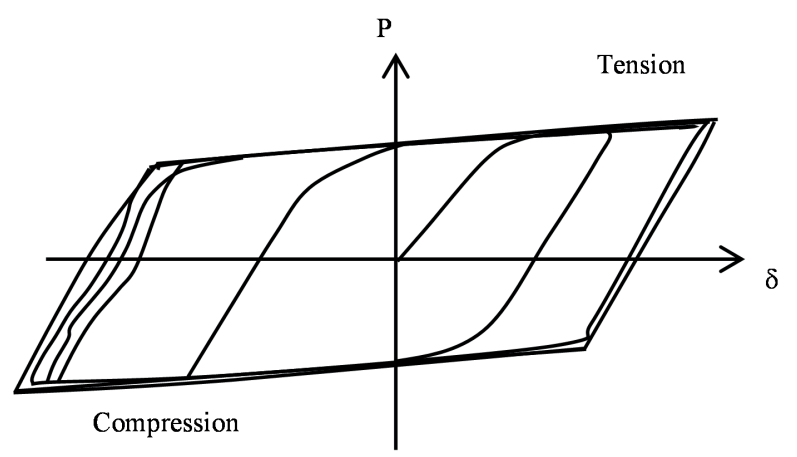

(b)

Fig. 1 Energy dissipation of two different bracing systems (a) normal bracing, (b) buckling restrained bracing 
flexibility of foundation and underlying soil surrounded foundation (inertial interaction). Two main methods are used in practical SSI problems for detailed analysis: the direct method and the substructure method [35].

\subsection{Problem statement}

The overall purpose of this study is to investigate the effects of the outrigger position on the seismic performance of tall buildings and to find the optimal configuration of energy dissipation outrigger based on the seismic response of the structure considering nonlinear SSI effects. Determining the optimum location of the outrigger has been one of the most critical challenges in tall structures with an outrigger system. In previous studies, it is assumed that the structure has a rigid base, and the SSI effects are ignored. In the seismic excitation, however, the input earthquake motion is applied to the soil underlying the structure. The presence of soil alters the input motion and causes it to be different from free-field motion. Therefore, analyzing the structure without considering the SSI effects is not logical.

Moreover, in previous papers, the optimum position of conventional outriggers (which buckle subjected to the axial compression loads) is obtained based on parameters such as top deflection and drift ratio. For example, Tavakoli et al. [19] investigate the dynamic analysis of a 30-story outrigger brace frame. The main purpose of this paper was a comparison between the responses of the elastic and in-elastic fixed base outrigger system with those of the elastic and in-elastic structure placed on a layered soil (only one layered soil was studied). Besides, the conventional outrigger system was used in the early mentioned paper. Besides, only the pressure-dependent multi yield material was utilized to simulate the soil model (layered sand soil). Finally, the El Centro earthquake was used to study the effect of elastic and in-elastic behaviors of the structures on the optimum location of the outrigger system.

In the present study, as BRBs are used in the outrigger system instead of conventional braces, the additional damping is introduced as an essential parameter to enhance the capacity of energy dissipation. Therefore, the additional damping is used as an additional parameter to determine the optimum location of the BRB outrigger. For this purpose, different high-rise 2-D braced steel buildings (20-, 25-, 30- and 35-story) rested on three different types of soils (soft clay, medium sand, and dense sand), are considered. Then, these structures are analyzed subjected to a set of earthquake motions, and the seismic performance of each structure is measured considering nonlinear SSI effects. The seismic performance is measured in terms of drift ratio, story displacement, base shear, hysteresis behavior (additional damping) for different positions of outrigger in highrise 2-D braced steel buildings. The effects of the outrigger position on seismic responses are studied, and the optimal location is determined accordingly. The results are compared with fixed-base models to show the effects of SSI on the seismic responses and the optimal outrigger position of a system with energy dissipation outrigger. Finally, to show the improved performance of structures with BRBs, the seismic performance of 2-D braced buildings with energy dissipation outrigger is compared under frequent, rare, and basic earthquakes. Also, two constitutive models, including of pressure-dependent (for sand soil) and pressure in-dependent (for clay soil) multi yield material, were utilized to simulate the soil models.

\section{Details of structure and soil}

The structural plan of the studied buildings with a different height (20-, 25-, 30- and 35-story) is shown in Fig. 2(a). One of the central frames is selected as the outrigger braced frame for each example which is shown in Fig. 2(a).

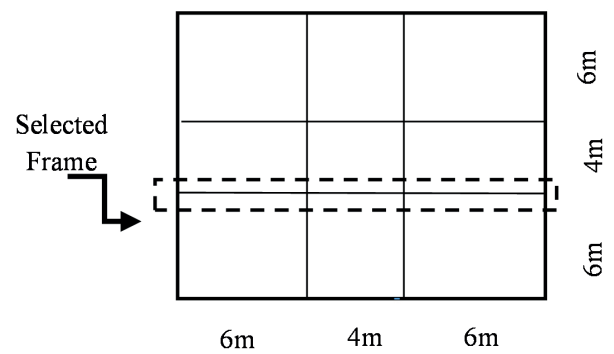

(a)

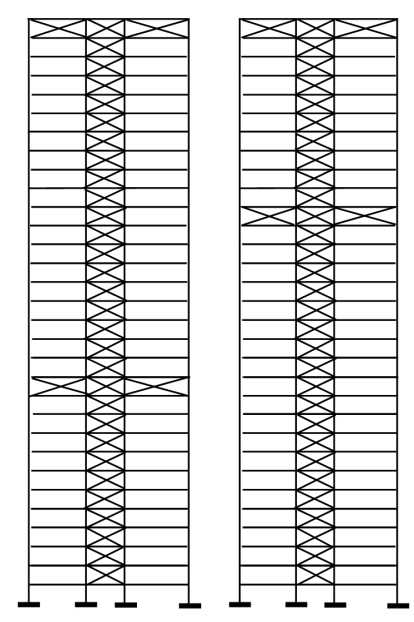

(b)

Fig. 2 (a) Structural plan for studied buildings, (b) Schematic outrigger braced frame with outriggers at different locations 
The configurations of the considered outrigger braced frames for the 30 -story building with different locations for the outrigger system are depicted in Fig. 2(b). In this study, two different outrigger systems are investigated; normal outrigger braced and buckling restrained outrigger braced systems that are represented as NOR-OBF and BRB-OBF, respectively. For each system, two outriggers are provided; one outrigger is fixed at the top story, and the location of other outrigger changes from bottom to the top story. NOR-OBF (3-20) implies a system whit normal outriggers provided at $3^{\text {th }}$ and $20^{\text {th }}$ stories. Similarly, buckling restrained outriggers that are located at $8^{\text {th }}$ and $20^{\text {th }}$ stories are represented by BRB-OBF (8-20).

The structures are designed based on the requirement of AISC-360-05 [48] and ASCE-SEI7-16 [49]. The yield strength of the steel used for structural members is $235 \mathrm{MPa}$. The story height is about $3.2 \mathrm{~m}$. All beam connections are assumed to be fully restrained, and all truss joints are assumed to be pinned at both ends.

The outrigger braced system is rested on a soil deposit comprised of 50-meters of three kinds of different soils (i.e., medium sand, soft clay, and dense sand). The soil domain in this study is $100 \mathrm{~m}$ wide, and constant crossplane thickness is $5 \mathrm{~m}$, which is equal to centerline distances of neighboring frames under plane strain condition. The main properties needed to define the constitutive behavior of underlying soil are mass density, shear wave velocity, and Poisson's ratio, which are considered, and other parameters like, shear and bulk moduli are calculated based on them. The other soil properties are determined according to the constitutive model, which is used to simulate the soil. In this study, the pressure-dependent multi yield material and pressure independent multi yield material are adopted as the constitutive model of sandy soil and soft clay, respectively. The mechanical properties of the underlying soil are illustrated in Table 1.

In this paper, the direct method applied using a numerical code in OpenSees, aims to consider the nonlinear behavior of structure and soil simultaneously. In the direct method, the whole soil-foundation-structure system is considered as a unique system; the free-field motion is applied at the boundaries of the soil domain, and the entire system is analyzed in a single step. This method is adequate for modeling the nonlinear behavior of soil and structure [35].

OpenSees is an open-source software capable of simulating advanced structures and geotechnical models. The SSI configuration is shown in Fig. 3.
Table 1 Material parameters for the underlying soil

\begin{tabular}{lcccc}
\hline $\begin{array}{l}\text { Model } \\
\text { soil parameters }\end{array}$ & $\begin{array}{c}\text { Parameter } \\
\text { index }\end{array}$ & $\begin{array}{c}\text { Medium } \\
\text { sand [50] }\end{array}$ & $\begin{array}{c}\text { Soft } \\
\text { clay [50] }\end{array}$ & $\begin{array}{c}\text { Dense } \\
\text { sand [50] }\end{array}$ \\
\hline $\begin{array}{l}\text { Mass density } \\
\left.\text { (ton } / \mathrm{m}^{3}\right)\end{array}$ & $\rho$ & 2.00 & 1.30 & 2.10 \\
$\begin{array}{l}\text { Bulk modulus } \\
\text { (kPa) }\end{array}$ & $B$ & $3 \times 10^{5}$ & $6.5 \times 10^{4}$ & $3.9 \times 10^{5}$ \\
$\begin{array}{l}\text { Friction angle } \\
\text { Poisson ratio }\end{array}$ & $\varphi$ & 37 & 0 & 40 \\
$\begin{array}{l}\text { Reference confining } \\
\text { pressure (kPa) }\end{array}$ & $\vartheta$ & 0.35 & 0.43 & 0.35 \\
$\begin{array}{l}\text { Peak shear strain } \\
\text { Shear wave velocity }\end{array}$ & $\gamma_{r}$ & 80 & - & 80 \\
(m/sec) & $v_{s}$ & 340 & 150 & 650 \\
\hline
\end{tabular}

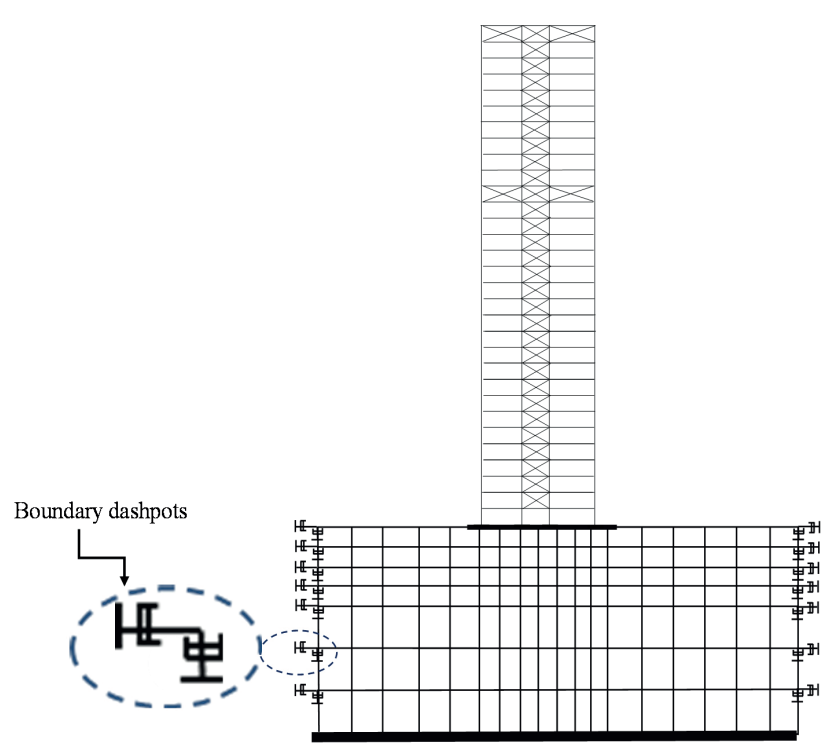

Fig. 3 Configuration of the SSI system in the OpenSees software

The total number of soil elements in the horizontal and vertical directions is 64 and 30, respectively. As a result, there are 1920 elements for the soil model. The dimensions of the elements are $2 \times 2 \mathrm{~m}$. In the horizontal direction, in less than 6 meters to the structure, the dimensions of elements reduce to 1 meter. In the vertical direction, however, the dimensions of elements reduce to 1 meter only in less than 10 meters to the soil surface. As a result, the dimensions of elements are $1 \times 1,10$ meters to the surface vertically, and 6 meters to the structure horizontally. This setup is displayed in Fig. 3, which results in a tinier mesh size closer to the structure. The tenfold transverse size of outrigger braced frames is chosen as soil size with viscose boundary put on transverse boundary of soil, (50 m height and $100 \mathrm{~m}$ wide); in this way, the soil dimension is large enough to absorb all vibrating waves and causes convergence based on [44]. Besides, a mesh size of $1 \times 1 \mathrm{~m}$ 
is suitable for the soil domain since it is smaller than the minimum wavelength propagating of the system [51]. Therefore, the convergence will occur in the answers based on $[44,51]$.

\section{Numerical modeling}

\subsection{Constitutive model of structure and soil}

For predicting the elastic-plastic behavior of structural members, steel 01 is used. This material is considered to have equal tension and compression yield stress. The strainstress behavior of steel 01 is shown in Fig. 4.

In this study, a set of multi-yield-surfaces (nested surfaces), which are of the Von Mises type are employed to simulate sandy soil underlying the foundation. This model is implemented in OpenSees as pressure multi yield material, and it is a useful model to simulate monotonic and cyclic behavior of sands and soil-structure interaction under seismic loading (Fig. 5(a)). This elastic-plastic material is capable of simulating properties of sandy soil, which is a pressure-sensitive type of soil. These properties include dilatancy (shear-induced volume contraction or dilation) and non-flow liquefaction. Pressure multi yield material is employed to obtain soil response under drained condition; it remains elastic under gravity load, and in the subsequent seismic loading phase, the plastic response of soil is induced based on nested surfaces concept.

For simulating the nonlinear shear behavior of soft clay, the multi-yield-surfaces $J_{2}$ plasticity (Von Mises) model is used (Fig. 5(b)). This model is implemented in OpenSees as the pressure independent multi yield material and is capable of simulating monotonic and cyclic responses of soil material whose shear behavior is insensitive to the confinement change.

\subsection{Development of the soil-structure model}

The structural members are modeled to behave nonlinearly, so beams and columns are modeled using nonlinear beam-column elements. The structural elements have spread plasticity along the length of the members. Besides, the fiber section is used for all elements. Two different types of braces are considered for modeling NOR and BRB outriggers. For modeling the post-buckling behavior of outrigger elements in the NOR system, an initial imperfection is applied at the element's mid-span. In the BRB system, braces are modeled to carry the axial forces and bear the compression up to yielding before buckling occurs. Four node quad elements are used to model the 2D soil domain with plane strain conditions. Each node has two degrees of freedom to represent the drained condition of the soil. A counterclockwise pattern is adopted for soil elements connectivity. Pressure-dependent multiyield material is assigned to soil elements to model the nonlinear behavior of sandy soil underlying the outrigger braced structure.

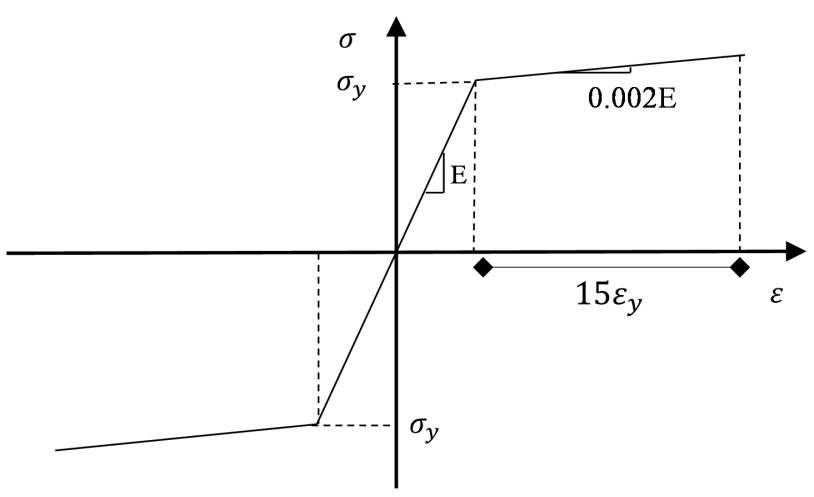

Fig. 4 Stress-strain behavior for steel [50]

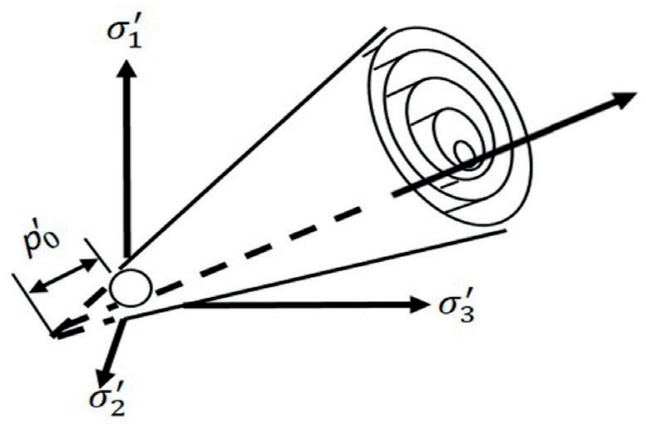

(a)

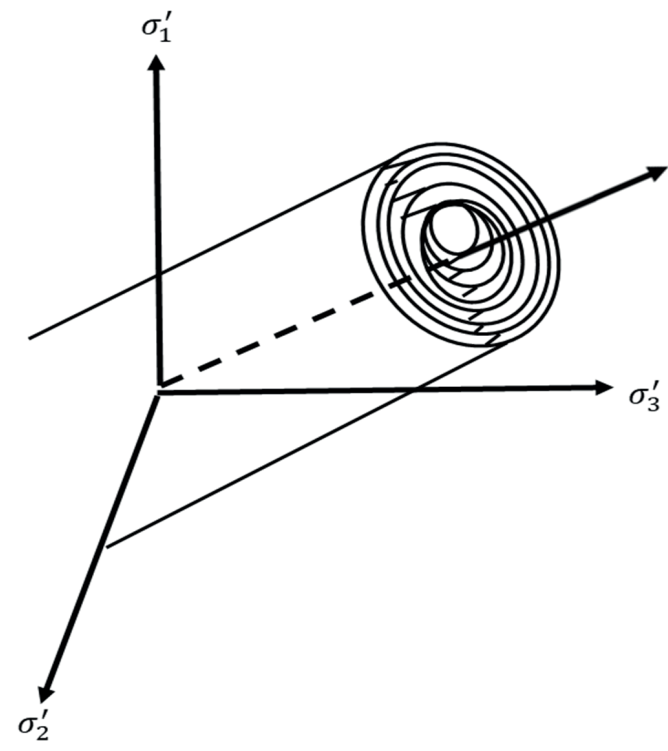

(b)

Fig. 5 a) Pressure dependent multi yield soil material model (for sandy soil) b) Pressure independent multi yield soil material model (for clay soil) [52] 


\subsubsection{Boundary condition}

Soil medium is an infinite medium. In SSI analysis, it is modeled as a finite region. So proper defining boundary condition of this truncated soil is one of the most critical issues in SSI. The artificial boundary of the truncated soil should be modeled to transfer all vibrating waves out of the soil domain without any reflection. One of the most commonly used boundary conditions is the viscose boundary introduced by [53]. Viscose boundary is equal to a series of dampers that are tangential and normal to the boundaries of the soil domain and absorb the energy of vibrating waves (Fig. 3). Normal and shear stresses on the boundary, which are absorbed by dampers, are defined as follows:

$\sigma=a \rho v_{p} w$

$\tau=b \rho v_{s} u$

in which $v_{p}, v_{s}$ are dilatational and shear wave velocity of propagation, respectively. Also, $w, u$ show the vertical and tangential velocity of particle motion. The parameters $\rho$ and $\vartheta$ are the mass density and Poisson ratio of the soil, respectively, and the parameters $a$ and $b$ are dimensionless parameters. Dashpot nodes which are defined on the boundary are connected by zero-length elements, and the viscous uniaxial material is assigned to these elements to define the boundary dashpot in the OpenSees software.

\subsection{Equations of motion}

The dynamic equilibrium of the soil-structure system is used to carry out the time-domain numerical analysis as follows:

$$
[\boldsymbol{M}]\{\ddot{u}\}+[\boldsymbol{C}]\{\dot{\boldsymbol{u}}\}+[\boldsymbol{K}]\{\boldsymbol{u}\}=-[\boldsymbol{M}]\{\boldsymbol{l}\}\left\{\boldsymbol{u}_{\boldsymbol{g}}\right\} .
$$

In Eq. (3), $[\boldsymbol{M}]$ is the mass matrix of the soil-structure system, $[\boldsymbol{C}]$ represents viscose damping matrix which is calculated based on Rayleigh damping and $[\boldsymbol{K}]$ is the stiffness matrix of the whole system. Also, $\{l\}$ shows the influence vector. Different numerical methods can be used in the dynamic analysis of structures [54]. In this paper, Newmark's method is adopted for numerical dynamic analysis of structures [55].

\section{Selection of earthquake ground motions}

In this study, three sets of ground motions are used, each set stands for a different hazard level, $50 \%$ in 50 years (frequent earthquakes), $10 \%$ in 50 years (basic earthquakes), and $2 \%$ in 50 years (rare earthquakes). Each hazard level is denoted by a set of 20 ground motions. These motions were extended under the FEMA/SAC project [56] for stiff soil sites and scenarios of earthquakes in the Los Angeles area. Table (A1) represents the details about these ground motions included; earthquake names, magnitude, distance from the fault, peak ground acceleration (see Appendix A). As it is shown in Table (A1), these motions included a vastrange of characteristics mentioned above. The mean res-ponse spectra for a $10 \%$ hazard level, including; spectral acceleration and spectral displacement, is represented in Fig. 6.

\section{Results}

\subsection{Eigenvalue analysis}

In the following section, the results of eigenvalue and nonlinear dynamic time-history analyses are discussed. The eigenvalue analysis reveals that considering the SSI and outrigger position can be useful in the estimation of seismic response. The fundamental periods of different high-rise buildings (i.e., 20-, 25-, 30- and 35-story) for flexible-base (medium sand) and fixed-base condition (all structures with a fixed location for outrigger on the

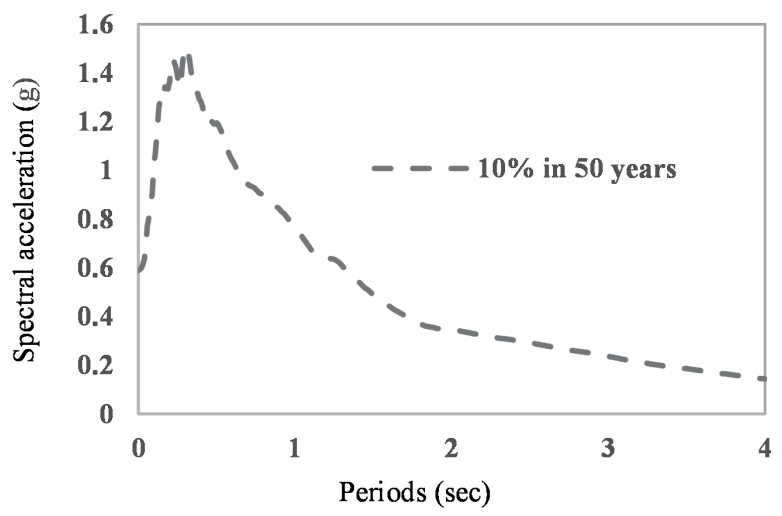

(a)

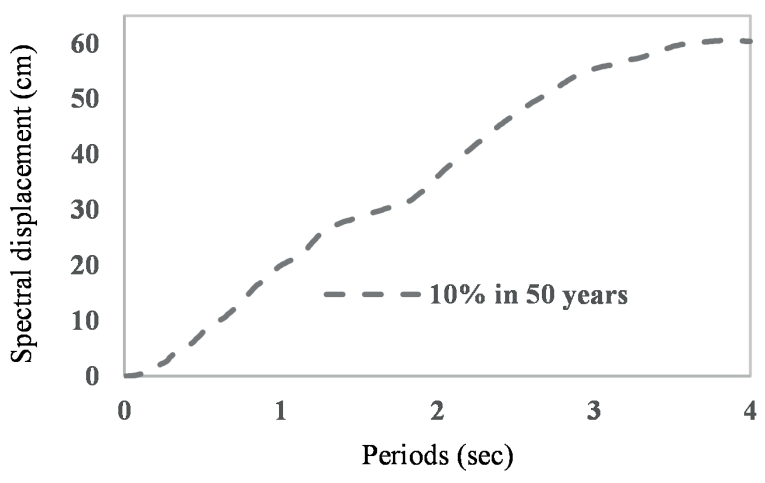

(b)

Fig. 6 a) Mean acceleration response spectra b) mean displacement response spectra 
top story) are shown in Table 2 to study the SSI effect. As it is evident from this table, SSI has a significant effect on increasing fundamental period; so, it can affect seismic demands. The effect of the outrigger position on the first period for the 20-story building can be seen in Fig. 7. In this figure, each bar shows the fundamental period of the structure with outrigger in a specific location. The first bar from the bottom shows the period of the 2-D braced building with no outrigger, whereas the second one shows the period of the 2-D braced building with one outrigger at the top. The third bar up to the last one shows the fundamental period of structures with a fixed outrigger on the top and a second outrigger with changing position from the first to the last story. Each bar shows the position of the second outrigger from the first to the last story of the building.

Table 2 Fixed-base and flexible-base periods for different high rise 2D outrigger-braced building

\begin{tabular}{lccc}
\hline & Fixed base $(T)$ & Flexible base $\left(T^{\prime}\right)$ & $T^{\prime} / T$ \\
\hline BR-OBF(20) & 1.71 & 1.898 & 1.11 \\
BR-OBF(25) & 2.22 & 2.5 & 1.13 \\
BR-OBF(30) & 2.56 & 2.73 & 1.07 \\
BR-OBF(35) & 3.37 & 3.7 & 1.1 \\
\hline
\end{tabular}

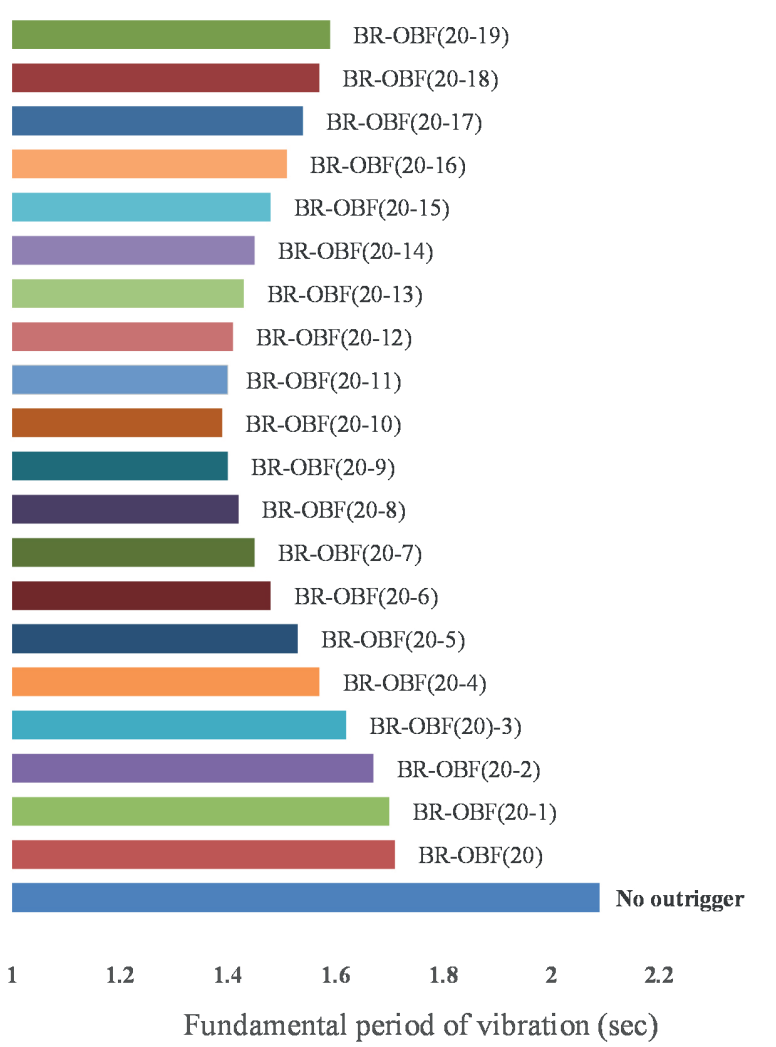

Fig. 7 Fundamental periods of vibration for 20-story 2D outrigger braced building
It has been illustrated in Fig. 7 that adding an outrigger reduces the fundamental period significantly compared to a system with no outrigger. So, this makes the structure stiffer. The subsequent addition of the second outrigger enhances the stiffness of the structure. Shifting the second outrigger along the structure's height changes the fundamental period of vibration and structural stiffness. For other structures, Table 3 shows the fundamental period for different positions of the outrigger. According to Fig. 7 and Table 3, for all structures with a different number of stories, placing the second outrigger in 0.4 to 0.6 of the building's total height of 2D outrigger braced buildings results in a stiffer structure.

\subsection{Dynamic analysis}

The results of nonlinear dynamic time history analysis for the flexible base (three different soil types) and fixedbase structures are discussed in the following sections. It should be noted that in all figures and calculations, the mean values of different seismic parameters for seismic motions of hazard levels of $10 \%$ in 50 years, are presented. In these analyses, the position of outrigger changes from first to the top story, and the mean seismic responses are calculated. Therefore, the effect of the outrigger position on seismic demand is determined to find the optimal position. Different optimization methods can be used in solving engineering problems [57-63].

\subsubsection{Story displacement}

In Fig. 8, the story displacements (peak absolute displacement) of 2-D outrigger braced structures for different stories considering the SSI effects (for the medium sand) have been shown. As it is illustrated, by adding the outrigger at

Table 3 Fundamental period of 2-D buildings with outrigger in the different locations

\begin{tabular}{lccc}
\hline Outrigger location & 25-story & 30-story & 35 -story \\
& 2.69 & 3.03 & 3.98 \\
\hline One outrigger at top & 2.22 & 2.56 & 3.37 \\
Second outrigger at $0.1 H$ & 2.14 & 2.51 & 3.25 \\
second outrigger at $0.2 H$ & 2.02 & 2.38 & 3.12 \\
second outrigger at $0.3 H$ & 1.9 & 2.27 & 2.97 \\
second outrigger at $0.4 H$ & 1.82 & 2.2 & 2.88 \\
second outrigger at $0.5 H$ & 1.79 & 2.17 & 2.84 \\
second outrigger at $0.6 H$ & 1.81 & 2.19 & 2.87 \\
second outrigger at $0.7 H$ & 1.87 & 2.24 & 2.94 \\
second outrigger at $0.8 H$ & 1.95 & 2.3 & 3.03 \\
second outrigger at $0.9 H$ & 2.02 & 2.37 & 3.13 \\
\hline
\end{tabular}




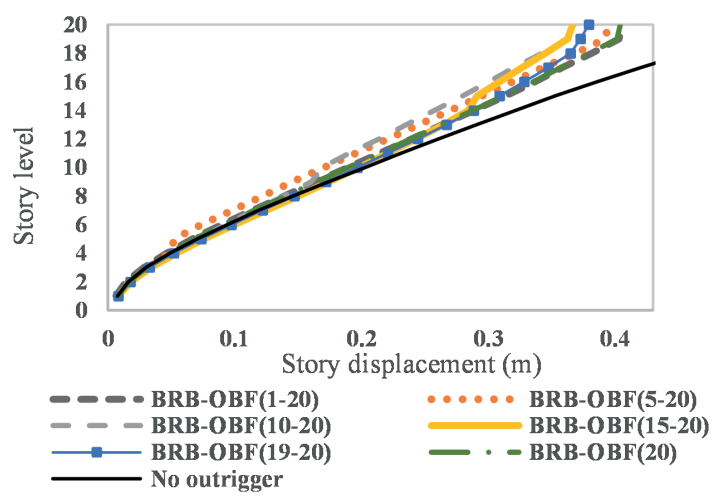

(a)

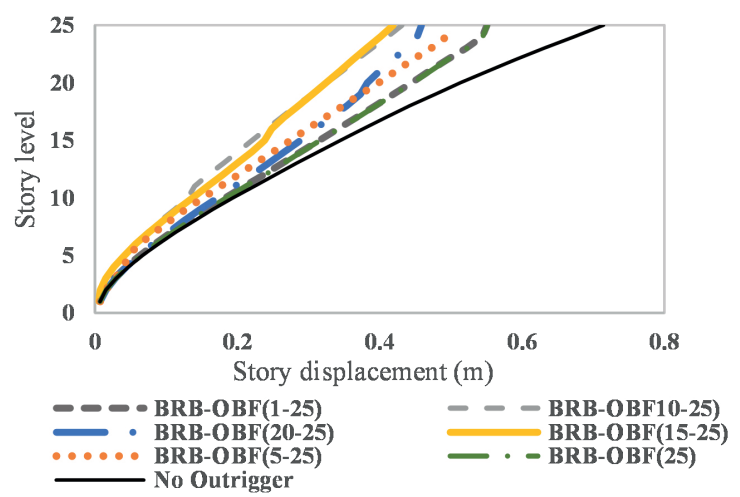

(b)

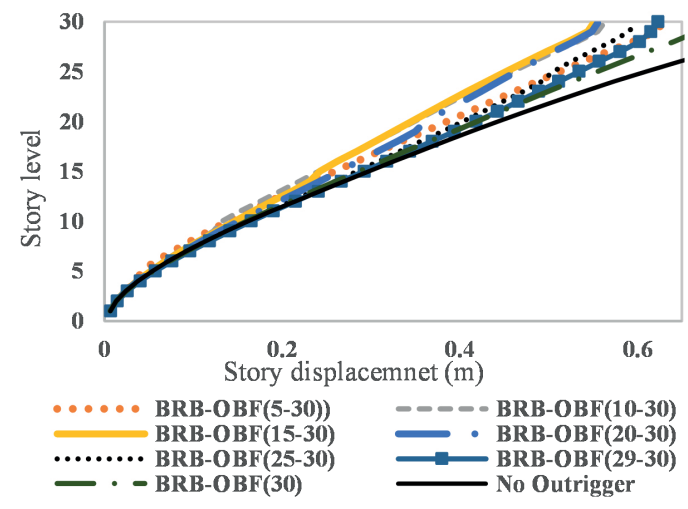

(c)

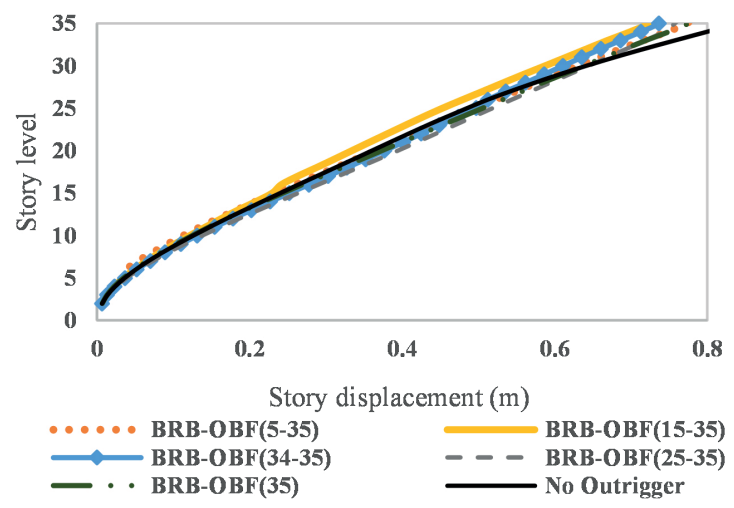

(d)

Fig. 8 Story displacement for 20-, 25-, 30- and, 35-story 2D outrigger brace buildings the top story, the story displacements decrease in comparison to the system without an outrigger. Subsequent addition of the second outrigger at other story reduces the peak absolute displacement more. To illustrate the foundation flexibility and nonlinear SSI effects, the maximum displacements (roof displacements) for different locations of the outrigger system in the 25-story braced building for different base conditions are plotted in Fig. 9. In this figure, the horizontal axis represents the top deflection, and the vertical shows the dimensionless outrigger location (the ratio of outrigger height to the total height of the building). The top displacement for other 2-D braced buildings is presented in Table 4. As it is apparent in Fig. 9 and Table 4, the flexibility of foundation causes the increment of top displacement, and this result can be interpreted as a reduction in the overall stiffness of outrigger buildings due to foundation movements and soil-structure effects. This trend for increasing displacement in flexible base buildings (with more considerable fundamental period than fixed base) is also apparent from spectral displacement (Fig. 6(b)) in which increasing period of vibration increases the spectral displacement. As is evident in Fig. 9 and Table 4, by decreasing the soil stiffness, the amount of top displacement is increased, and the optimal location, which effectively controls the top deflection, moves to a higher position.

In Table 3, the fixed outrigger has been located at the top story for all studied states.

\subsubsection{Inter-story drift ratio}

In this section, the inter-story drift ratios of different 2D BRB-outrigger braced high-rise steel buildings are depicted in Fig. 10. For all different studied buildings, buildings without an outrigger system represent larger values of the drift ratio. It is evident from all graphs that there is an abrupt change in the drift ratio at the outrigger

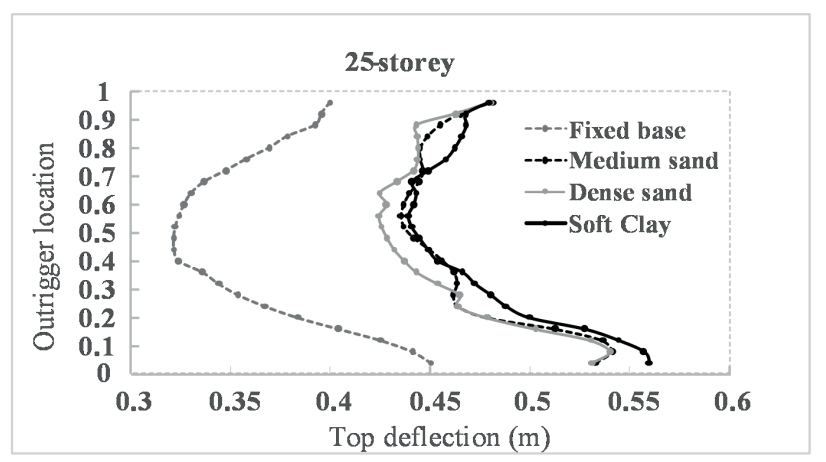

Fig. 9 Top displacement for 25-story 2D outrigger brace buildings 
Table 4 Top displacement for 20, 30- and 35-story 2D outrigger brace buildings for different location of outrigger

\begin{tabular}{|c|c|c|c|c|}
\hline \multirow{2}{*}{$\begin{array}{l}\text { Outrigger } \\
\text { location }\end{array}$} & \multicolumn{4}{|c|}{20 -story } \\
\hline & Fixed base & $\begin{array}{l}\text { Stiff } \\
\text { sand }\end{array}$ & $\begin{array}{l}\text { Medium } \\
\text { sand }\end{array}$ & $\begin{array}{l}\text { Soft } \\
\text { clay }\end{array}$ \\
\hline $0.1 H$ & 0.2915 & 0.4017 & 0.4065 & 0.4401 \\
\hline $0.2 H$ & 0.2830 & 0.3852 & 0.3993 & 0.4772 \\
\hline $0.3 H$ & 0.2711 & 0.3579 & 0.3900 & 0.4216 \\
\hline $0.4 H$ & 0.2603 & 0.3403 & 0.3751 & 0.3660 \\
\hline $0.5 H$ & 0.2621 & 0.2861 & 0.3661 & 0.3666 \\
\hline $0.6 H$ & 0.2653 & 0.2884 & 0.3605 & 0.3594 \\
\hline $0.7 H$ & 0.2659 & 0.2879 & 0.3658 & 0.3571 \\
\hline $0.8 H$ & 0.2700 & 0.3052 & 0.3712 & 0.4055 \\
\hline $0.9 H$ & 0.2736 & 0.3183 & 0.3751 & 0.4079 \\
\hline$H$ & 0.2793 & 0.3244 & 0.3793 & 0.4021 \\
\hline \multirow{2}{*}{$\begin{array}{l}\text { Outrigger } \\
\text { location }\end{array}$} & \multicolumn{4}{|c|}{30 -story } \\
\hline & Fixed base & $\begin{array}{l}\text { Stiff } \\
\text { sand }\end{array}$ & $\begin{array}{l}\text { Medium } \\
\text { sand }\end{array}$ & $\begin{array}{l}\text { Soft } \\
\text { clay }\end{array}$ \\
\hline $0.1 H$ & 0.5191 & 0.6535 & 0.6892 & 0.7045 \\
\hline $0.2 H$ & 0.4753 & 0.6144 & 0.6368 & 0.6529 \\
\hline $0.3 H$ & 0.4523 & 0.5741 & 0.5807 & 0.5888 \\
\hline $0.4 H$ & 0.4423 & 0.5595 & 0.5658 & 0.5855 \\
\hline $0.5 H$ & 0.4349 & 0.5516 & 0.5509 & 0.5783 \\
\hline $0.6 H$ & 0.4436 & 0.5493 & 0.5464 & 0.5735 \\
\hline $0.7 H$ & 0.4662 & 0.5621 & 0.5613 & 0.5947 \\
\hline $0.8 H$ & 0.4950 & 0.5901 & 0.5849 & 0.6181 \\
\hline $0.9 H$ & 0.5148 & 0.6133 & 0.6135 & 0.6471 \\
\hline$H$ & 0.5231 & 0.6231 & 0.6297 & 0.6608 \\
\hline \multirow[b]{2}{*}{$\begin{array}{l}\text { Outrigger } \\
\text { location }\end{array}$} & \multicolumn{4}{|c|}{35 -story } \\
\hline & Fixed base & $\begin{array}{l}\text { Stiff } \\
\text { sand }\end{array}$ & $\begin{array}{l}\text { Medium } \\
\text { sand }\end{array}$ & $\begin{array}{l}\text { Soft } \\
\text { clay }\end{array}$ \\
\hline $0.1 H$ & 0.7658 & 0.7866 & 0.8881 & 0.9694 \\
\hline $0.2 H$ & 0.7689 & 0.7828 & 0.8740 & 0.9327 \\
\hline $0.3 H$ & 0.7424 & 0.7793 & 0.8382 & 0.8679 \\
\hline $0.4 H$ & 0.7297 & 0.7745 & 0.8281 & 0.8420 \\
\hline $0.5 H$ & 0.7248 & 0.7661 & 0.826 & 0.8249 \\
\hline $0.6 H$ & 0.7232 & 0.7424 & 0.8237 & 0.8453 \\
\hline $0.7 H$ & 0.7418 & 0.748 & 0.8197 & 0.8193 \\
\hline $0.8 H$ & 0.7580 & 0.7489 & 0.8501 & 0.8684 \\
\hline $0.9 H$ & 0.7652 & 0.7301 & 0.8694 & 0.8908 \\
\hline$H$ & 0.7652 & 0.7344 & 0.8721 & 0.8980 \\
\hline
\end{tabular}

position because the outrigger makes that story stiffer. The inter-story drift ratios become more non-uniform as the building's height increases.

To figure out the SSI effect and to find the optimum configuration for the outrigger system, the maximum interstory drift ratio experienced by the 25 -story $2 \mathrm{D}$ frame for different outrigger location is depicted in Fig. 11. In this figure, the vertical axis implies the height of the 2D frame in which the belt truss is located, and the horizontal one shows the maximum inter-story drift.

The maximum inter-story drift ratio for other 2D buildings are presented in Table 5. As it is apparent in Fig. 12 and Table 5, the maximum inter-story drift ratio is increased when the base condition changes from fix to flexible. As it is shown, considering SSI shifts the optimum location of outrigger to the upper height of buildings. The optimum position for 20-, 25-, 30- and 35-story 2D-BRB outrigger braced buildings with the fixed base condition is 0.4 to 0.45 of the building's total height, whereas, in buildings with a flexible base, the optimum location shifts to upper height. In the condition in which the building is rested on the soft clay (soil with the lowest stiffness), the optimum location is at $0.7 \mathrm{H}$, which is highest among other conditions. Fig. 10 displays, the lower positions of outrigger are the worst for controlling the drift ratio.

\subsubsection{Additional damping}

One of the main reasons for using BRBs in outrigger systems is their efficiency in the energy dissipation of the outrigger system. Indeed, BRBs cause stable behavior by preventing buckling of diagonal members and increase the amount of dissipation of input energy and add additional damping to the structure. The additional damping can be calculated by Eq. (4) [55]:

$\xi_{a}=\frac{E_{d}}{4 \pi E_{s}}$,

in which $\xi_{a}$ is additional damping, $E_{s}$ is the elastic energy of the whole structure and $E_{d}$ shows the amount of dissipated energy by BRB elements. This value is calculated based on the restricted area by force-deformation curves. The mean additional damping for different locations of BRB outrigger is plotted in Fig. 12 subjected to the ground motions of hazard level of $10 \%$ in 50 years to figure out whether the location of BRB outrigger alters the amount of dissipated energy or not.

In Fig. 12, the horizontal axis shows dimensionless outrigger height, and the vertical axis stands for additional damping related to each outrigger location. It is understood from Fig. 12 that when a 2-D BRB outrigger building becomes taller the maximum additional damping increases as well. Also, placing the BRB outrigger at a lower height in the building is not so useful to increase additional damping. Still, as BRB outrigger location shifts 

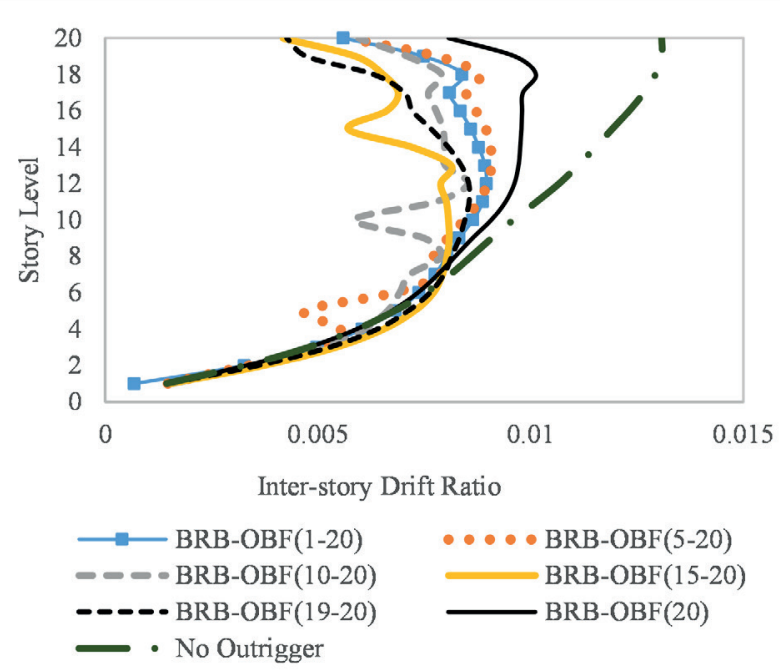

(a)

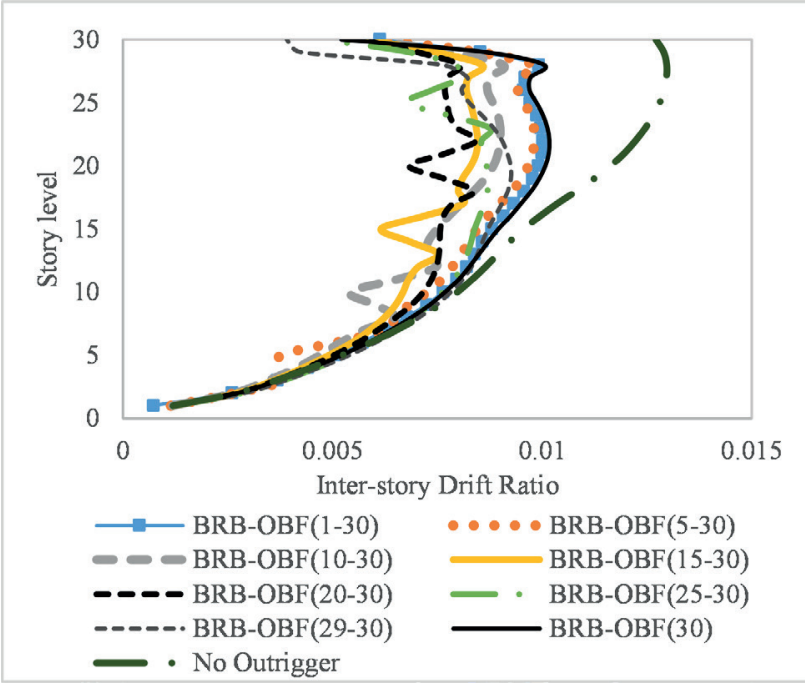

(c)

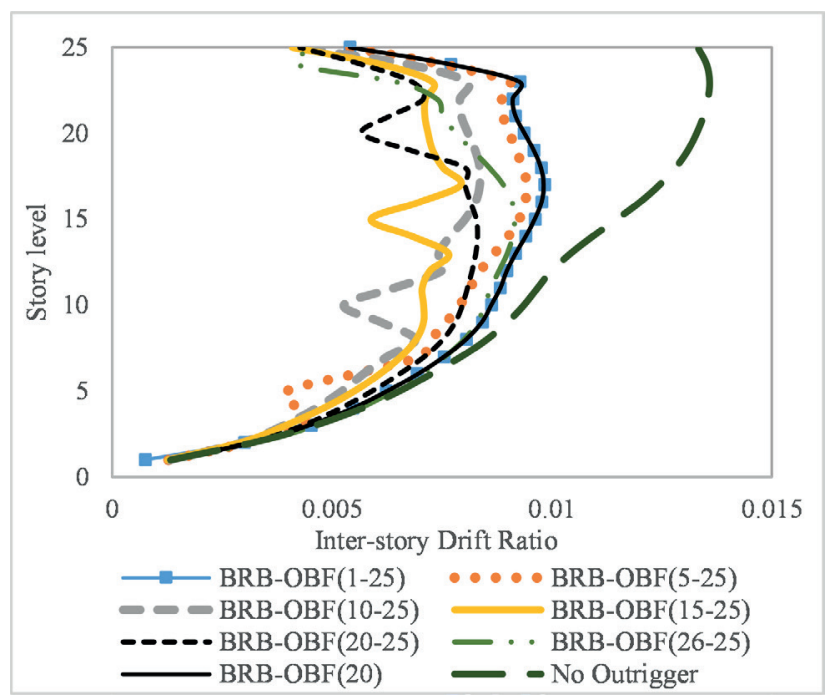

(b)

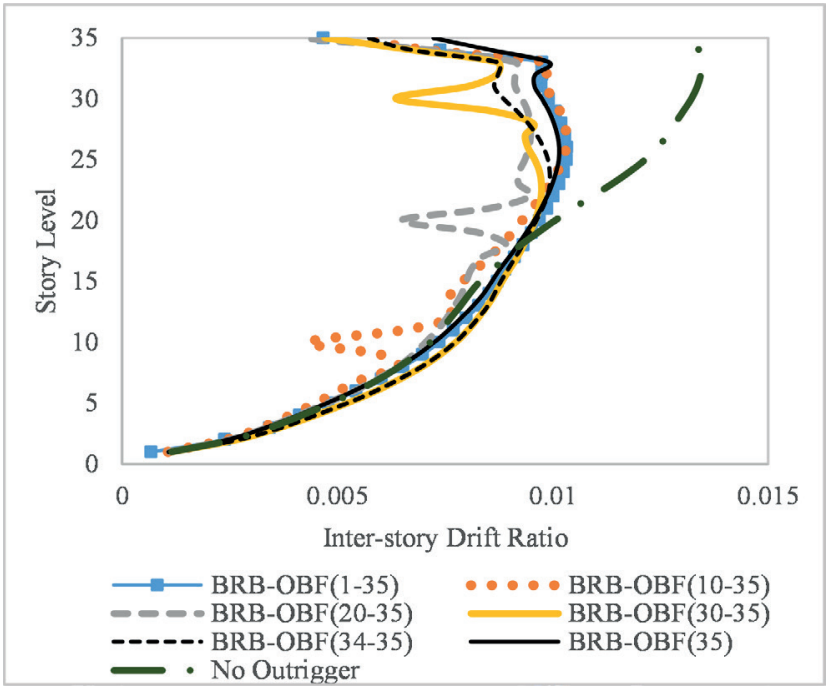

(d)

Fig. 10 Inter-storey drift ratio for (a) 20-, (b) 25-, (c) 30-, and (d) 35-storey 2D outrigger brace buildings

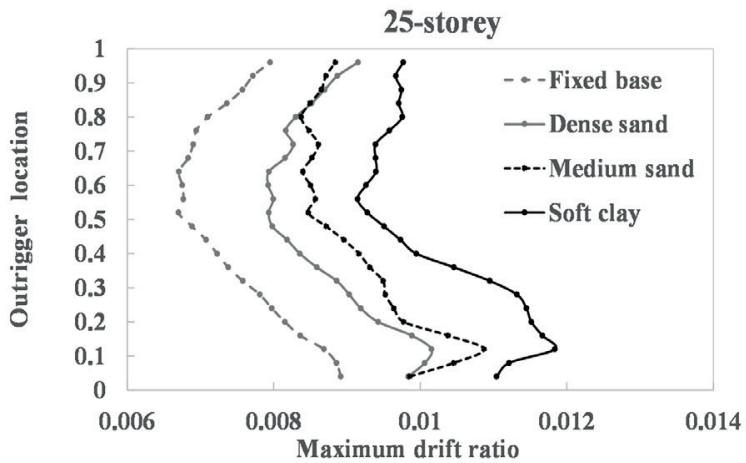

Fig. 11 Inter-storey drift ratio for 25-storey 2D outrigger brace building

to upper stories, the amount of additional damping is increased, then, it is decreased again, as outrigger placed at story near the top of the building. Fig. 12 shows that the 0.45 to 0.65 of the building's total height is the optimal location for the BRB outrigger in all different studied buildings. It also proves increasing the additional damping significantly in the 2-D outrigger-based buildings.

\section{Comparison of the seismic results of BRB outrigger with conventional outrigger}

In the following section, to show the improvement of seismic behavior of a high rise building due to BRBs, the structural behavior for the 30-story high-rise building with energy dissipation outrigger is compared to one with ordinary outrigger. For this purpose, the outrigger is placed at its optimum location, which is determined in the previous section. $0.5 \mathrm{H}$ of the 30 -story building is laid in the range of optimal outrigger height, which can reduce top deflection and inter-story drift in a decent way besides increasing additional damping of system reasonably. Therefore, the 
Table 5 Top displacement for 20-, 30- and 35-story 2D outrigger brace buildings for different location of outrigger $(\times 100)$

\begin{tabular}{|c|c|c|c|c|}
\hline \multirow[b]{2}{*}{$\begin{array}{l}\text { Outrigger } \\
\text { location }\end{array}$} & \multicolumn{4}{|c|}{20 -story } \\
\hline & Fixed base & $\begin{array}{l}\text { Stiff } \\
\text { sand }\end{array}$ & $\begin{array}{l}\text { Medium } \\
\text { sand }\end{array}$ & $\begin{array}{l}\text { Soft } \\
\text { clay }\end{array}$ \\
\hline $0.1 H$ & 0.785 & 0.923 & 0.920 & 1.367 \\
\hline $0.2 H$ & 0.807 & 0.895 & 0.925 & 1.464 \\
\hline $0.3 H$ & 0.782 & 0.853 & 0.886 & 1.250 \\
\hline $0.4 H$ & 0.754 & 0.830 & 0.856 & 1.188 \\
\hline $0.5 H$ & 0.736 & 0.827 & 0.853 & 1.144 \\
\hline $0.6 H$ & 0.715 & 0.784 & 0.829 & 1.147 \\
\hline $0.7 H$ & 0.715 & 0.792 & 0.824 & 1.124 \\
\hline $0.8 H$ & 0.726 & 0.799 & 0.828 & 1.235 \\
\hline $0.9 H$ & 0.732 & 0.832 & 0.850 & 1.177 \\
\hline \multirow{2}{*}{$\begin{array}{l}\text { Outrigger } \\
\text { location }\end{array}$} & \multicolumn{4}{|c|}{ 30-story } \\
\hline & Fixed base & $\begin{array}{l}\text { Stiff } \\
\text { sand }\end{array}$ & $\begin{array}{c}\text { Medium } \\
\text { sand }\end{array}$ & $\begin{array}{l}\text { Soft } \\
\text { clay }\end{array}$ \\
\hline $0.1 H$ & 0.894 & 1.001 & 1.170 & 1.300 \\
\hline $0.2 H$ & 0.857 & 0.968 & 1.099 & 1.253 \\
\hline $0.3 H$ & 0.803 & 0.917 & 1.023 & 1.140 \\
\hline $0.4 H$ & 0.773 & 0.894 & 0.953 & 1.107 \\
\hline $0.5 H$ & 0.714 & 0.858 & 0.892 & 1.054 \\
\hline $0.6 H$ & 0.722 & 0.849 & 0.865 & 1.031 \\
\hline $0.7 H$ & 0.728 & 0.854 & 0.894 & 1.017 \\
\hline $0.8 H$ & 0.769 & 0.879 & 0.934 & 1.048 \\
\hline $0.9 H$ & 0.791 & 0.902 & 0.942 & 1.088 \\
\hline \multirow{2}{*}{$\begin{array}{l}\text { Outrigger } \\
\text { location }\end{array}$} & \multicolumn{4}{|c|}{ 35-story } \\
\hline & Fixed base & $\begin{array}{l}\text { Stiff } \\
\text { sand }\end{array}$ & $\begin{array}{l}\text { Medium } \\
\text { sand }\end{array}$ & $\begin{array}{l}\text { Soft } \\
\text { clay }\end{array}$ \\
\hline $0.1 H$ & 0.951 & 1.044 & 1.053 & 1.487 \\
\hline $0.2 H$ & 0.927 & 1.056 & 1.071 & 1.456 \\
\hline $0.3 H$ & 0.895 & 1.024 & 1.045 & 1.400 \\
\hline $0.4 H$ & 0.866 & 0.990 & 1.007 & 1.332 \\
\hline $0.5 H$ & 0.826 & 0.943 & 0.967 & 1.282 \\
\hline $0.6 H$ & 0.836 & 0.929 & 0.952 & 1.268 \\
\hline $0.7 H$ & 0.857 & 0.964 & 0.969 & 1.261 \\
\hline $0.8 H$ & 0.863 & 0.979 & 0.991 & 1.234 \\
\hline $0.9 H$ & 0.899 & 0.986 & 0.994 & 1.245 \\
\hline
\end{tabular}

outrigger is placed at 15 th story and seismic behavior in terms of drift demand, story shear and hysteresis behavior of BRB-OBF (outrigger braced with BRB) and NOR-OBF (outrigger braced with ordinary braces) are compared subjected to the three different sets of seismic ground motion (50\%, $10 \%$ and $2 \%$ in 50 years).

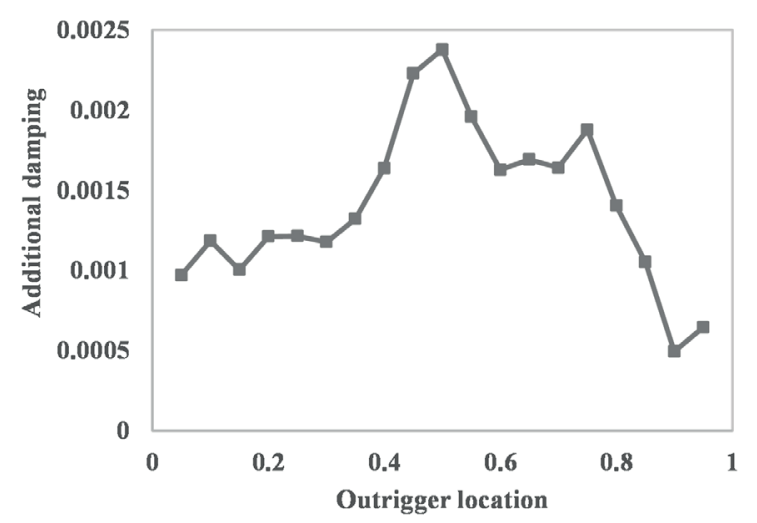

(a)

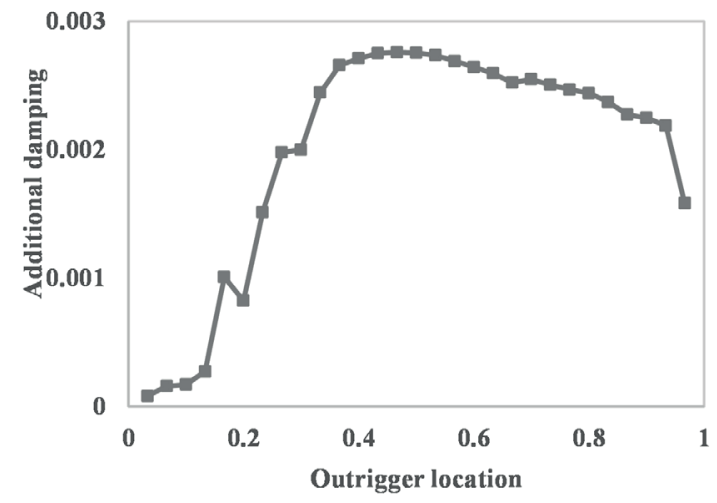

(b)

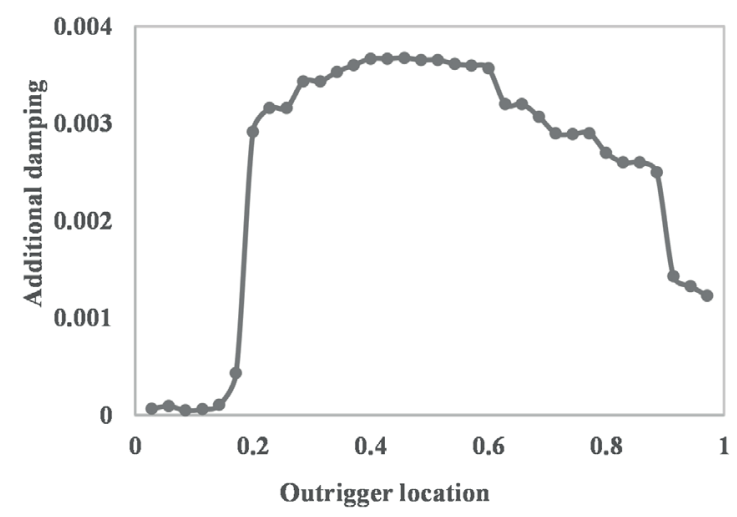

(c)

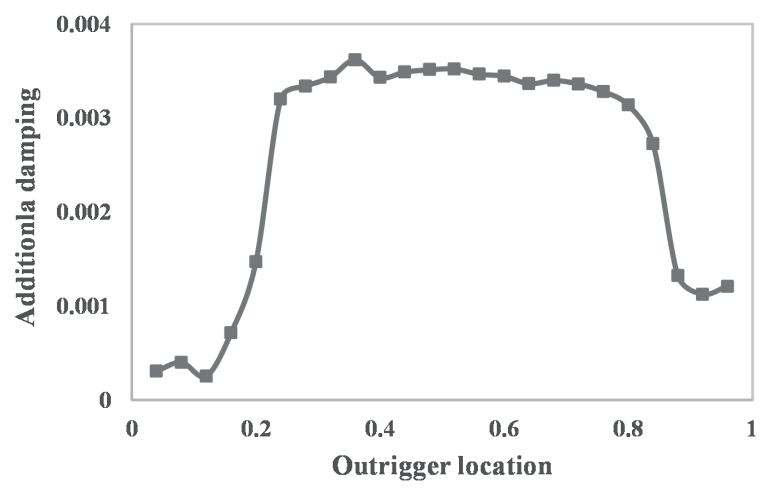

(d)

Fig. 12 Additional damping of 20-, 25-, 30-, and 35-storey 2D outrigger brace building 


\subsection{Drift demand}

One of the most crucial index in evaluating seismic behavior is the inter-story drift ratio. The mean drift ratio under frequent, basic, and rare earthquakes $(50 \%, 10 \%$, and $2 \%$ in 50 years) for both systems are calculated and compared in Fig. 13. As it is indicated, under a basic earthquake, the drift in both systems is almost the same, as both systems remained nearly in the elastic range. As the strength of ground motion increases, the drift difference becomes more apparent. Under rare earthquakes, BRB-OBF systems decrease the drift ratio more significantly than NOR-OBF systems. Also, drift distribution is more uniform in BRB-OBF systems, and sudden change of drift in the story, which is strengthened with BRB outrigger, is less than the NOR-OBF system.

\subsection{Shear demand}

Story shear is one of the other seismic parameters, which is determined for the 30-story building. Fig. 14 shows a comparison between the story shear in systems with BRB and conventional outrigger. In this figure, the horizontal axis indicates the story shear force, and the vertical shows the story level. For frequent earthquakes, the story shear force along the height of the building is the same for both NOR-OBF and BRB-OBF systems. As it is shown, the sudden change of story shear at the location of the outrigger becomes more moderate in the BRB-OBF system than the NOR-OBF system.

\section{Conclusions}

In this paper, the seismic performance of 2-D braced buildings is studied considering SSI effects to obtain the optimal location of the BRB outrigger system. The following results are obtained:

Considering SSI has a significant effect on the fundamental period of the structures. Therefore, it can affect seismic demand considerably, and ignoring it, is not logical.

Adding a fixed BRB outrigger at the top of the buildings reduces the first period and makes the structure stiffer.

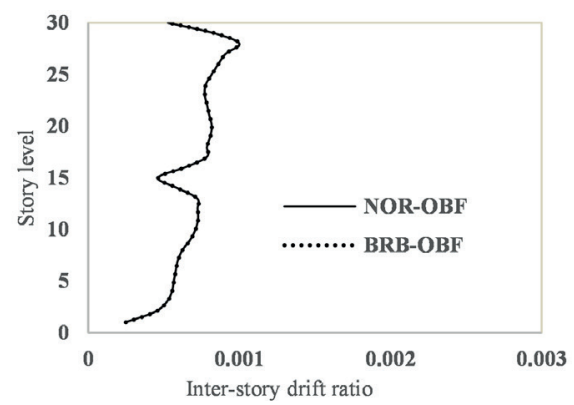

(a)

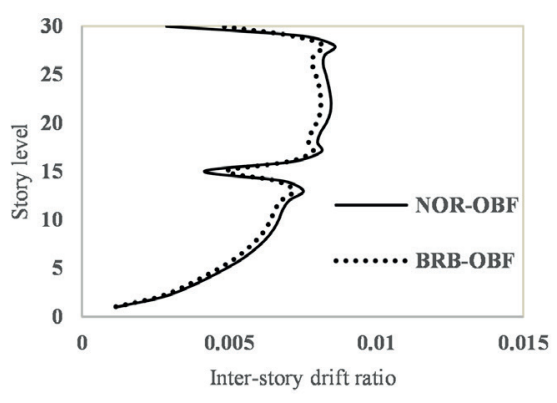

(b)

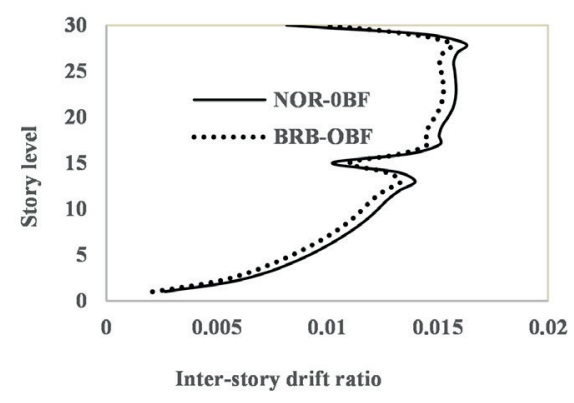

(c)

Fig. 13 Inter-story drift ratio for different sets of seismic ground motion
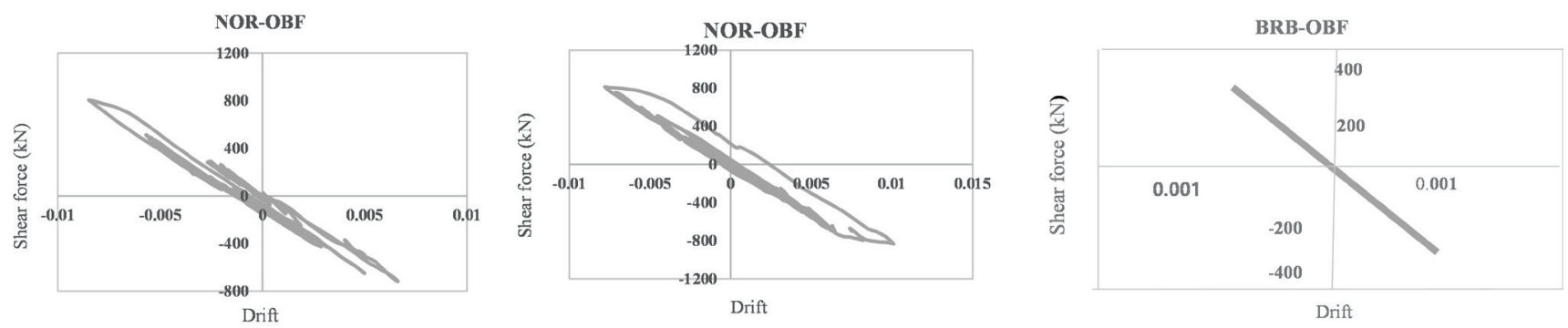

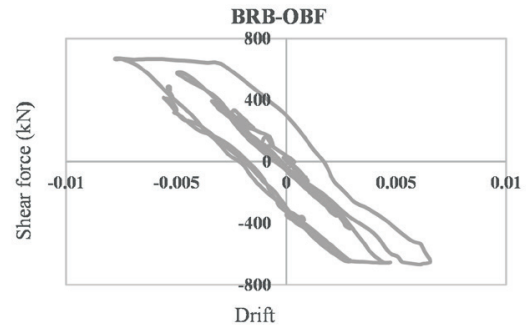

(a)

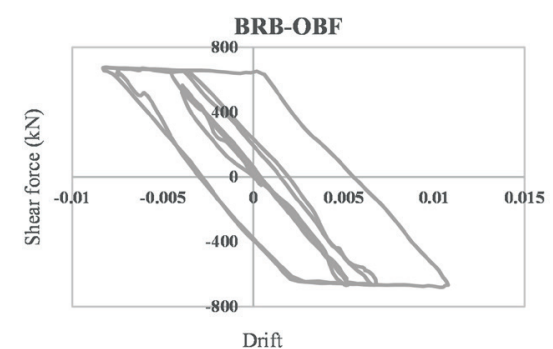

(b)

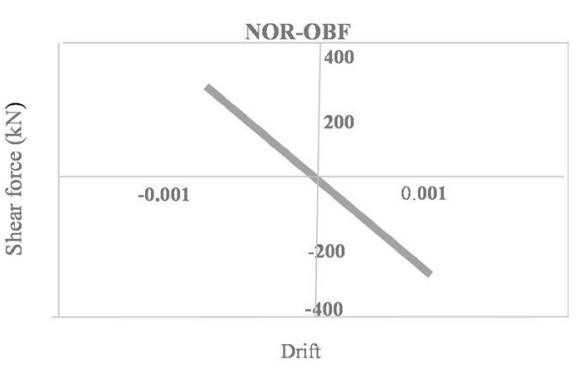

(c)

Fig. 14 Shear-drift behavior of the 15th story a), for ground motion LA 25 ( $2 \%$ in 50 years), b) for ground motion LA 17 ( $2 \%$ in 50 years), c) for ground motion LA 45 (2\% in 50 years) 
Placing the second BRB outrigger at 0.4 to 0.6 of 2-D braced buildings height $(H)$, increases the structure's stiffness more than any other locations.

The flexibility of the foundation causes the increment of top displacement and inter-story drift ratio; this can be interpreted as a reduction in the overall stiffness of outrigger buildings due to foundation movements and the effects of the soil-structure interaction.

In a fixed based structure, the optimal outrigger location is determined 0.5 of the building's height $(H)$, considering top deflection and inter-story drift ratio criteria. However, the SSI affects the optimal location of BRB outrigger and shifts it to an upper position. The higher position for the optimum location of BRB outrigger is also

\section{References}

[1] Alavi, A., Rahgozar, R., Torkzadeh, P. "Stiffnes-based Approach for Preliminary Design of Framed Tube Structures", International Journal of Engineering, 30(11), pp. 1664-1672, 2017. [online] Available at: http://www.ije.ir/article_73051.html

[2] Heidari, A., Rahgozar, R., Kamgar, R. "Free vibration analysis of tall building with geometrical discontinuites", Asian Journal of Civil Engineering, 15(1), pp. 107-122, 2014. [online] Available at: https://www.sid.ir/en/journal/ViewPaper.aspx?ID=353464

[3] Kamgar, R., Saadatpour, M. M. "A simple mathematical model for free vibration analysis of combined system consisting of framed tube, shear core, belt truss and outrigger system with geometrical discontinuities", Applied Mathematical Modelling, 36(10), pp. 4918-4930, 2012.

https://doi.org/10.1016/j.apm.2011.12.029

[4] Masoodi, A. R. "Analytical solution for optimum location of belt truss in outrigger system based on stability analysis", Proceedings of the Institution of Civil Engineers - Structures and Buildings, 172(5), pp. 382-388, 2019. https://doi.org/10.1680/jstbu.17.00187

[5] Mazzotta, V., Brunesi, E., Nascimbene, R. "Numerical Modeling and Seismic Analysis of Tall Steel Buildings with Braced Frame Systems", Periodica Polytechnica Civil Engineering, 61(2), pp. 196-208, 2017.

https://doi.org/10.3311/PPci.9469

[6] Mohammadnejad, M., Haji Kazemi, H. "Dynamic response analysis of a combined system of framed tubed, shear core and outrigger-belt truss", Asian Journal of Civil Engineering, 18(8), pp. 1211-1228, 2017. [online] Available at: https://ajce.bhrc.ac.ir/ Journal-Volumes-Issues/agentType/View/PropertyID/9496

[7] Samadi, M., Jahan, N. "Determining the effective level of outrigger in preventing collapse of tall buildings by IDA with an alternative damage measure", Engineering Structures, 191, pp. 104-116, 2019.

https://doi.org/10.1016/j.engstruct.2019.03.095 obtained for the softer soil. The optimal locations of different 2-D buildings in dense sand, medium sand, and soft clay are obtained at $0.6 H, 0.65 H$, and $0.7 H$, respectively.

Using BRB in an outrigger system instead of conventional outriggers can improve the seismic response of 2-D buildings effectively, especially under rare earthquakes. It should be mentioned that the structure may experience the inelastic responses subjected to the rare earthquakes.

In this paper, the additional damping parameter is also studied as one of the most important goals of using BRB outrigger systems. The BRB outrigger system is enhancing the capacity of energy dissipation. According to this criterion, the optimal location of $\mathrm{BRB}$ outrigger, which maximizes the additional damping, is calculated $0.45 H$ to $0.65 H$.

[8] Tavakoli, R., Kamgar, R., Rahgozar, R. "Seismic Performance of Outrigger-Braced System Based on Finite Element and ComponentMode Synthesis Methods", Iranian Journal of Science and Technology, Transactions of Civil Engineering, 2019. https://doi.org/10.1007/s40996-019-00299-3

[9] Hoenderkamp, J. C. D., Bakker, M. C. M. "Analysis of high-rise braced frames with outriggers", The Structural Design of Tall and Special Buildings, 12(4), pp. 335-350, 2003. https://doi.org/10.1002/tal.226

[10] Kamgar, R., Rahgozar, P. "Reducing static roof displacement and axial forces of columns in tall buildings based on obtaining the best locations for multi-rigid belt truss outrigger systems", Asian Journal of Civil Engineering, 20, pp. 759-768, 2019. https://doi.org/10.1007/s42107-019-00142-0

[11] Kamgar, R., Rahgozar, R. "Determination of optimum location for flexible outrigger systems in non-uniform tall buildings using energy method", International Journal of Optimization in Civil Engineering, 5(4), pp. 433-444, 2015. [online] Available at: http:// ijoce.iust.ac.ir/browse.php?a_id=226\&sid=1\&slc_lang=en

[12] Kamgar, R., Rahgozar, R. "Determination of critical excitation in seismic analysis of structures", Earthquakes and Structures, 9(4), pp. 875-891, 2015. https://doi.org/10.12989/eas.2015.9.4.875

[13] Kamgar, R., Rahgozar, R. "Determination of optimum location for flexible outrigger systems in tall buildings with constant cross section consisting of framed tube, shear core, belt truss and outrigger system using energy method", International Journal of Steel Structures, 17, pp. 1-8, 2017. https://doi.org/10.1007/s13296-014-0172-8

[14] Kamgar, R., Shojaee, S., Rahgozar, R. "Rehabilitation of tall buildings by active control system subjected to critical seismic excitation", Asian Journal of Civil Engineering, 16(6), pp. 819-833, 2015. [online] Available at: https://ajce.bhrc.ac.ir/ Journal-Volumes-Issues/agentType/View/PropertyID/5788 
[15] Patil, D. M., Sangle, K. K. "Seismic Behaviour of Outrigger Braced Systems in High Rise 2-D Steel Buildings", Structures, 8(1), pp. 1-16, 2016. https://doi.org/10.1016/j.istruc.2016.07.005

[16] Rahgozar, P. "Free Vibration of Tall Buildings using Energy Method and Hamilton's Principle", Civil Engineering Journal, 6(5), pp. 945-953, 2020. https://doi.org/10.28991/cej-2020-03091519

[17] Sharifi, Y., Aviz, H. "Effect of outrigger-belt truss location on the dynamic response of high-rise building subjected to blast loading", Journal of Engineering, Design and Technology, 14(1), pp. $54-77,2016$. https://doi.org/10.1108/JEDT-12-2013-0084

[18] Tavakoli, R., Kamgar, R., Rahgozar, R. "The Best Location of Belt Truss System in Tall Buildings using Multiple Criteria Subjected to Blast Loading", Civil Engineering Journal, 4(6), pp. 1338-1353, 2018.

https://doi.org/10.28991/cej-0309177

[19] Tavakoli, R., Kamgar, R., Rahgozar, R. "Seismic performance of outrigger-belt truss system considering soil-structure interaction", International Journal of Advanced Structural Engineering, 11, pp. 45-54, 2019. https://doi.org/10.1007/s40091-019-0215-7

[20] Kamath, K., Divya, N., Rao, A. U. "A Study on Static and Dynamic Behavior of Outrigger Structural System for Tall Buildings", Bonfring International Journal of Industrial Engineering and Management Science, 2(4), pp. 15-20, 2012. https://doi.org/10.9756/BIJIEMS.1655

[21] Asgarian, B., Amirhesari, N. "A comparison of dynamic nonlinear behavior of ordinary and buckling restrained braced frames subjected to strong ground motion", The Structural Design of Tall and Special Buildings, 17(2), pp. 367-386, 2008. https://doi.org/10.1002/tal.358

[22] Chen, Y., McFarland, D. M., Wang, Z., Spencer, Jr., B. F., Bergman, L. A. "Analysis of Tall Buildings with Damped Outriggers", Journal of Structural Engineering, 136(11), pp. 1435-1443, 2010. https://doi.org/10.1061/(ASCE)ST.1943-541X.0000247

[23] Huang, B., Takeuchi, T. "Dynamic Response Evaluation of Damped-Outrigger Systems with Various Heights", Earthquake Spectra, 33(2), pp. 665-685, 2017. https://doi.org/10.1193/051816EQS082M

[24] Smith, R. J., Willford, M. R. "The damped outrigger concept for tall buildings", The Structural Design of Tall and Special Buildings, 16(4), pp. 501-517, 2007. https://doi.org/10.1002/tal.413

[25] Tan, P., Fang, C., Zhou, F. "Dynamic characteristics of a novel damped outrigger system", Earthquake Engineering and Engineering Vibration, 13, pp. 293-304, 2014. https://doi.org/10.1007/s11803-014-0231-3

[26] Jiang, H., Li, S., Zhu, Y. "Seismic performance of high-rise buildings with energy-dissipation outriggers", Journal of Constructional Steel Research, 134, pp. 80-91, 2017. https://doi.org/10.1016/j.jcsr.2017.03.013
[27] Lin, P.-C., Takeuchi, T., Matsui, R. "Seismic performance evaluation of single damped-outrigger system incorporating buckling-restrained braces", Earthquake Engineering and Structural Dynamics, 47(12), pp. 2343-2365, 2018.

https://doi.org/10.1002/eqe.3072

[28] Zhou, Y., Zhang, C., Lu, X. "Seismic performance of a damping outrigger system for tall buildings", Structural Control and Health Monitoring, 24(1), Article number: e1864, 2017. https://doi.org/10.1002/stc.1864

[29] Ju, Y. K., Kim, M.-H., Kim, J., Kim, S.-D. "Component tests of buckling-restrained braces with unconstrained length", Engineering Structures, 31(2), pp. 507-516, 2009. https://doi.org/10.1016/j.engstruct.2008.09.014

[30] Kim, D.-H., Lee, C.-H., Ju, Y. K., Kim, S.-D. "Subassemblage test of buckling-restrained braces with H-shaped steel core", The Structural Design of Tall and Special Buildings, 24(4), pp. 243-256, 2015. https://doi.org/10.1002/tal.1164

[31] Gholizadeh, S., Ebadijalal, M. "Performance based discrete topology optimization of steel braced frames by a new metaheuristic", Advances in Engineering Software, 123, pp. 77-92, 2018. https://doi.org/10.1016/j.advengsoft.2018.06.002

[32] Gholizadeh, S., Poorhoseini, H. "Seismic layout optimization of steel braced frames by an improved dolphin echolocation algorithm", Structural and Multidisciplinary Optimization, 54, pp. 10111029, 2016. https://doi.org/10.1007/s00158-016-1461-y

[33] Habibi, A.-R., Asadi, K. "Seismic performance of reinforced concrete moment resisting frames with setback based on Iranian seismic code", International Journal of Civil Engineering, 12(1), pp. 41-54, 2014. [online] Available at: http://ijce.iust.ac.ir/browse. php?a_code $=$ A-10-759-1\&slc_lang $=$ en\&sid $=$ en

[34] Habibi, A., Vahed, M., Asadi, K. "Evaluation of Seismic Performance of RC setback frames", Structural Engineering and Mechanics, 66(5), pp. 609-619, 2018.

https://doi.org/10.12989/sem.2018.66.5.609

[35] Wolf, J. P. "Dynamic Soil-Structure Interaction", Prentice-Hall, Englewood Cliffs, NJ, USA, 1985.

[36] Gholizadeh, S., Shahrezaei, A. M. "Optimal placement of steel plate shear walls for steel frames by bat algorithm", The Structural Design of Tall and Special Buildings, 24(1), pp. 1-18, 2015. https://doi.org/10.1002/tal.1151

[37] Kramer, S. L. "Earthquake Geotechnical Engineering", 1st ed., Prentice Hall, Upper Saddle River, NJ, USA, 1996.

[38] Heidarzadeh, H., Kamgar, R. "Necessity of applying the concept of the steady state on the numerical analyses of excavation issues: laboratory, field and numerical investigations", Geomechanics and Geoengineering, 2020. https://doi.org/10.1080/17486025.2020.1755466

[39] Heidarzadeh, H., Kamgar, R. "Evaluation of the Importance of Gradually Releasing Stress Around Excavation Regions in Soil Media and the Effect of Liners Installation Time on Tunneling", Geotechnical and Geological Engineering, 38, pp. 2213-2225, 2020. https://doi.org/10.1007/s10706-019-01158-8 
[40] Kamgar, R., Gholami, F., Zarif Sanayei, H. R., Heidarzadeh, H. "Modified Tuned Liquid Dampers for Seismic Protection of Buildings Considering Soil-Structure Interaction Effects", Iranian Journal of Science and Technology, Transactions of Civil Engineering, 44, pp. 339-354, 2020. https://doi.org/10.1007/s40996-019-00302-x

[41] Kamgar, R., Khatibinia, M., Khatibinia, M. "Optimization criteria for design of tuned mass dampers including soil-structure interaction effect", International Journal of Optimization in Civil Engineering, 9(2), pp. 213-232, 2019. [online] Available at: http:// ijoce.iust.ac.ir/article-1-385-en.pdf

[42] Pap, Zs. B., Kollár, L. P. "Effect of Resonance in Soil-Structure Interaction for Finite Soil Layers", Periodica Polytechnica Civil Engineering, 62(3), pp. 676-684, 2018. https://oi.org/10.3311/PPci.11960

[43] Papadopoulos, M., Van Beeumen, R., François, S., Degrande, G., Lombaert, G. "Modal characteristics of structures considering dynamic soil-structure interaction effects", Soil Dynamics and Earthquake Engineering, 105, pp. 114-118, 2018. https://doi.org/10.1016/j.soildyn.2017.11.012

[44] Lu, X., Chen, B., Li, P., Chen, Y. "Numerical Analysis of Tall Buildings Considering Dynamic Soil-Structure Interaction", Journal of Asian Architecture and Building Engineering, 2(1), pp. $1-8,2003$. https://doi.org/10.3130/jaabe.2.1

[45] Cruz, C., Miranda, E. "Evaluation of soil-structure interaction effects on the damping ratios of buildings subjected to earthquakes", Soil Dynamics and Earthquake Engineering, 100, pp. 183-195, 2017

https://doi.org/10.1016/j.soildyn.2017.05.034

[46] Raychowdhury, P. "Seismic response of low-rise steel momentresisting frame (SMRF) buildings incorporating nonlinear soil-structure interaction (SSI)", Engineering Structures, 33(3), pp. $958-967,2011$.

https://oi.org/10.1016/j.engstruct.2010.12.017

[47] Torabi, H., Rayhani, M. T. "Three dimensional Finite Element modeling of seismic soil-structure interaction in soft soil", Computers and Geotechnics, 60, pp. 9-19, 2014. https://doi.org/10.1016/j.compgeo.2014.03.014

[48] American Institute of Steel Construction "AISC-360-05 Specification for Structural Steel Buildings", AISC, Chicago, IL, USA, 2005.

[49] American Society of Civil Engineers "ASCE-SEI7-16 Minimum Design Loads for Buildings and Other Structures", ASCE, Reston, VA, USA, 2016.

[50] Mazzoni, S., McKenna, F., Scott, M. H., Fenves, G. L. "OpenSees Command Language Manual", Pacific Earthquake Engineering Research (PEER) Center, Berkeley, CA, USA, 2006.

[51] Yazdani, H., Khatibinia, M., Gharehbaghi, S., Hatami, K. "Probabilistic Performance-Based Optimum Seismic Design of RC Structures Considering Soil-Structure Interaction Effects", ASCE-ASME Journal of Risk and Uncertainty in Engineering Systems, Part A: Civil Engineering, 3(2), Article number: G4016004, 2017.

https://doi.org/10.1061/AJRUA6.0000880
[52] Zhang, Y., Conte, J. P., Yang, Z., Elgamal, A., Bielak, J., Acero, G. "Two-Dimensional Nonlinear Earthquake Response Analysis of a Bridge-Foundation-Ground System", Earthquake Spectra, 24(2), pp. 343-386, 2008. https://oi.org/10.1193/1.2923925

[53] Lysmer, J., Kuhlemeyer, R. L. "Finite Dynamic Model for Infinite Media", Journal of the Engineering Mechanics Division, 95(4), pp. 859-878, 1969.

[54] Kamgar, R., Rahgozar, R. "A simple method for determining the response of linear dynamic systems", Asian Journal of Civil Engineering, 17(6), pp. 785-801, 2016. [online] Available at: https:/ajce.bhrc.ac.ir/Journal-Volumes-Issues/agentType/View/ PropertyID/7787

[55] Chopra, A. K. "Dynamics of Structures: Theory and Applications to Earthquake Engineering", 4th ed., Prentice-Hall, New York, NY, USA, 2012.

[56] Somerville, P., Smith, N. F., Punyamurthula, S., Ji, S. "Development of ground motion time histories for phase 2 of the FEMA/SAC steel project", Federal Emergency Management Agency, Washington, DC, USA, Rep. SAC/BD-97/04, 1997.

[57] Arzani, H., Kaveh, A., Kamalinejad, M. "Optimal Design of Pitched Roof Rigid Frames with Non-Prismatic Members Using Quantum Evolutionary Algorithm", Periodica Polytechnica Civil Engineering, 63(2), pp. 593-607, 2019. https://doi.org/10.3311/PPci.14091

[58] Kamgar, R., Samea, P., Khatibinia, M. "Optimizing parameters of tuned mass damper subjected to critical earthquake", The Structural Design of Tall and Special Buildings, 27(7), Article number: e1460, 2018. https://doi.org/10.1002/tal.1460

[59] Kaveh, A., Dadras, A., Malek, N. G. "Optimum stacking sequence design of composite laminates for maximum buckling load capacity using parameter-less optimization algorithms", Engineering with Computers, 35, pp. 813-832, 2019. https://doi.org/10.1007/s00366-018-0634-2

[60] Kaveh, A., Javadi, S. M. "Chaos-based firefly algorithms for optimization of cyclically large-size braced steel domes with multiple frequency constraints", Computers and Structures, 214, pp. $28-39,2019$

https://doi.org/10.1016/j.compstruc.2019.01.006

[61] Kaveh, A., Zarandi, M. M. M. "Optimal Design of SteelConcrete Composite I-girder Bridges Using Three Meta-Heuristic Algorithms", Periodica Polytechnica Civil Engineering, 63(2), pp. 317-337, 2019 https://doi.org/10.3311/PPci.12769

[62] Kaveh, A., Vazirinia, Y. "Optimization of Tower Crane Location and Material Quantity Between Supply and Demand Points: A Comparative Study", Periodica Polytechnica Civil Engineering, 62(3), pp. 732-745, 2018. https://doi.org/10.3311/PPci.11816

[63] Khatibinia, M., Gholami, H., Kamgar, R. "Optimal design of tuned mass dampers subjected to continuous stationary critical excitation", International Journal of Dynamics and Control, 6, pp. 1094-1104, 2018. https://doi.org/10.1007/s40435-017-0386-7 


\section{Appendix A}

Table 6 Earthquake ground motions

\begin{tabular}{|c|c|c|c|c|c|c|}
\hline Hazard level & SAC Name & Record & Earthquake Magnitude & Distance $(\mathrm{m})$ & Duration (sec) & PGA $\left(\mathrm{cm} / \mathrm{sec}^{2}\right)$ \\
\hline \multirow{20}{*}{$\begin{array}{l}50 \% \text { in } \\
50 \text { year }\end{array}$} & LA41 & Coyote Lake, 1979 & 5.7 & 8.8 & 39.38 & 578.34 \\
\hline & LA42 & Coyote Lake, 1979 & 5.7 & 8.8 & 39.38 & 326.81 \\
\hline & LA43 & Imperial Valley, 1979 & 6.5 & 1.2 & 39.09 & 140.67 \\
\hline & LA44 & Imperial Valley, 1979 & 6.5 & 1.2 & 39.08 & 109.45 \\
\hline & LA45 & Kern, 1952 & 7.7 & 107 & 78.6 & 141.49 \\
\hline & LA46 & Kern, 1952 & 7.7 & 107 & 78.6 & 156.02 \\
\hline & LA47 & Landers, 1992 & 7.3 & 64 & 79.98 & 331.22 \\
\hline & LA48 & Landers, 1992 & 7.3 & 64 & 79.98 & 301.74 \\
\hline & LA49 & Morgan Hill, 1984 & 6.2 & 15 & 59.98 & 312.41 \\
\hline & LA50 & Morgan Hill, 1984 & 6.2 & 15 & 59.98 & 535.88 \\
\hline & LA51 & Parkfield, 1966, Cholame 5W & 6.1 & 3.7 & 43.92 & 765.65 \\
\hline & LA52 & Parkfield, 1966, Cholame 5W & 6.1 & 3.7 & 43.92 & 619.36 \\
\hline & LA53 & Parkfield, 1966, Cholame 8W & 6.1 & 8 & 26.14 & 680.01 \\
\hline & LA54 & Parkfield, 1966, Cholame 8W & 6.1 & 8 & 26.14 & 775.05 \\
\hline & LA55 & North Palm Spirings ,1986 & 6 & 9.6 & 59.98 & 507.58 \\
\hline & LA56 & North Palm Spirings ,1986 & 6 & 9.6 & 59.98 & 371.66 \\
\hline & LA57 & San Fernando, 1971 & 6.5 & 1 & 79.46 & 248.14 \\
\hline & LA58 & San Fernando, 1971 & 6.5 & 1 & 79.46 & 226.54 \\
\hline & LA59 & Whittier, 1987 & 6 & 17 & 39.98 & 753.7 \\
\hline & LA60 & Whittier, 1987 & 6 & 17 & 39.98 & 469.07 \\
\hline \multirow{20}{*}{$\begin{array}{l}10 \% \text { in } \\
50 \text { year }\end{array}$} & LA1 & Imperial Valley,1940, El Centro & 6.9 & 10 & 39.38 & 452.03 \\
\hline & LA2 & Imperial Valley, 1940, El Centro & 6.9 & 10 & 39.38 & 662.88 \\
\hline & LA3 & Imperial Valley, 1979, Array \#05 & 6.5 & 4.1 & 39.38 & 386.04 \\
\hline & LA4 & Imperial Valley, 1979, Array \#05 & 6.5 & 4.1 & 39.38 & 478.65 \\
\hline & LA5 & Imperial Valley, 1979, Array \#06 & 6.5 & 1.2 & 39.08 & 295.69 \\
\hline & LA6 & Imperial Valley, 1979, Array \#06 & 6.5 & 1.2 & 39.08 & 230.08 \\
\hline & LA7 & Landers, 1992, Barstow & 7.3 & 36 & 79.98 & 412.98 \\
\hline & LA8 & Landers, 1992, Barstow & 7.3 & 36 & 79.98 & 417.49 \\
\hline & LA9 & Landers, 1992, Yermo & 7.3 & 25 & 79.98 & 509.7 \\
\hline & LA10 & Landers, 1992, Yermo & 7.3 & 25 & 79.98 & 353.35 \\
\hline & LA11 & Loma Prieta,1989, Gilroy & 7 & 12 & 39.98 & 652.49 \\
\hline & LA12 & Loma Prieta,1989,Gilroy & 7 & 12 & 39.98 & 950.93 \\
\hline & LA13 & Northridge,1994,Newhall & 6.7 & 6.7 & 59.98 & 664.93 \\
\hline & LA14 & Northridge,1994,Newhall & 6.7 & 6.7 & 59.98 & 664.49 \\
\hline & LA15 & Northridge,1994, Rinaldi RS & 6.7 & 7.5 & 14.945 & 523.3 \\
\hline & LA16 & Northridge,1994, Rinaldi RS & 6.7 & 7.5 & 14.945 & 568.58 \\
\hline & LA17 & Northridge,1994, Sylmar & 6.7 & 6.4 & 59.98 & 558.43 \\
\hline & LA18 & Northridge,1994, Sylmar & 6.7 & 6.4 & 59.98 & 801.44 \\
\hline & LA19 & North Palm Springs,1986 & 6 & 6.7 & 59.98 & 999.43 \\
\hline & LA20 & North Palm Springs,1986 & 6 & 6.7 & 59.98 & 967.61 \\
\hline
\end{tabular}




\begin{tabular}{|c|c|c|c|c|c|c|}
\hline Hazard level & SAC Name & Record & Earthquake Magnitude & Distance $(\mathrm{m})$ & Duration (sec) & PGA $\left(\mathrm{cm} / \mathrm{sec}^{2}\right)$ \\
\hline \multirow{20}{*}{$\begin{array}{l}2 \% \text { in } \\
50 \text { year }\end{array}$} & LA21 & Kobe & 6.9 & 3.4 & 59.98 & 1258 \\
\hline & LA22 & Kobe & 6.9 & 34 & 59.98 & 902.75 \\
\hline & LA23 & Loma Prieta & 7 & 3.5 & 24.99 & 409.95 \\
\hline & LA24 & Loma Prieta & 7 & 3.5 & 24.99 & 463.76 \\
\hline & LA25 & Northridge & 6.7 & 7.5 & 14.945 & 851.62 \\
\hline & LA26 & Northridge & 6.7 & 7.5 & 14.945 & 925.29 \\
\hline & LA27 & Northridge & 6.7 & 6.4 & 59.98 & 908.7 \\
\hline & LA28 & Northridge & 6.7 & 6.4 & 59.98 & 1304.1 \\
\hline & LA29 & Tabas & 7.4 & 1.2 & 49.98 & 793.45 \\
\hline & LA 30 & Tabas & 7.4 & 1.2 & 49.98 & 972.58 \\
\hline & LA31 & Elysian Park (simulated) & 7.1 & 17.5 & 29.99 & 1271.2 \\
\hline & LA32 & Elysian Park (simulated) & 7.1 & 17.5 & 29.99 & 1163.5 \\
\hline & LA33 & Elysian Park (simulated) & 7.1 & 10.7 & 29.99 & 767.26 \\
\hline & LA34 & Elysian Park (simulated) & 7.1 & 10.7 & 29.99 & 667.59 \\
\hline & LA35 & Elysian Park (simulated) & 7.1 & 11.2 & 29.99 & 973.16 \\
\hline & LA36 & Elysian Park (simulated) & 7.1 & 11.2 & 29.99 & 1079.3 \\
\hline & LA37 & Palos Verdes (simulated) & 7.1 & 1.5 & 59.98 & 697.84 \\
\hline & LA38 & Palos Verdes (simulated) & 7.1 & 1.5 & 59.98 & 761.31 \\
\hline & LA39 & Palos Verdes (simulated) & 7.1 & 1.5 & 59.98 & 490.58 \\
\hline & LA40 & Palos Verdes (simulated) & 7.1 & 1.5 & 59.98 & 613.28 \\
\hline
\end{tabular}

